\title{
Una llamada de "urgencia" para tutela cautelar en la justicia administrativa en Cuba
}

\author{
JOLENE PEREIRA ${ }^{1}$
}

\section{RESUMEN}

El régimen jurídico de la tutela cautelar que rige hoy por hoy para la justicia administrativa en Cuba, se basa en el principio de ejecutabilidad de los actos administrativos, y por tanto, en la regla de la no suspensión de las decisiones de la administración pública. El modelo construido tomó como referencia el sistema de justicia cautelar administrativa del derecho franco-español de finales del siglo XIX. En el siguiente trabajo se parte del presupuesto de la necesidad de un cambio de paradigma en torno a la ordenación jurídica de la tutela cautelar administrativa en Cuba, para la cual se aportan argumentos teóricos que justifican una modificación en pos de ampliar y reforzar el rol de la tutela cautelar en la jurisdicción contencioso-administrativa.

Palabras clave: tutela cautelar, jurisdicción contencioso-administrativa, daños por demora en las actuaciones, apariencia de buen derecho, suspensión de decisiones administrativas.

1 Licenciada en Derecho (2007), Universidad de La Habana, Cuba. Máster en Derecho y Medio Ambiente por la Universidad Internacional de Andalucía (2011), España, y máster en Derecho Constitucional y Administrativo por la Universidad de La Habana (2011), La Habana, Cuba. Ex jueza de la Sala de lo Civil y lo Administrativo del Tribunal Provincial de La Habana, La Habana, Cuba. Correo-e: pereira2284@gmail.com. Fecha de recepción: 12 de diciembre de 2014. Fecha de modificación: 2 de marzo de 2015. Fecha de aceptación: 10 de octubre de 2015. Para citar el artículo: Pereira, J. (2015). Una llamada de urgencia para tutela cautelar en la justicia administrativa en Cuba. Revista Digital de Derecho Administrativo n. ${ }^{\circ}$ 14, Universidad Externado de Colombia, pp. 129-172. DOI: http://dx.doi. org/10.18601/21452946.n14.08 


\section{An "urgent" call for interim judicial protection in Cuban administrative justice}

ABSTRACT

The legal regime of preventive adjudication that applies nowadays in Cuba is based on the principle of feasibility of administrative acts, and therefore, in the rule of no suspension of the decisions of the Administration. The Cuban model was built from a French-Spanish administrative preventive system that was applied in the late $19^{\text {th }}$ Century. The following paper seeks to demonstrate the need for change in the regulation of administrative preventive adjudication in Cuba. It provides theoretical arguments in order to justify the extension and the strengthening of preventive adjudication by administrative Courts.

Keywords: Interim judicial protection, Administrative Courts, Cuban Administrative Law, preventive adjudication by the judiciary, suspension of administrative decisions.

"El recurso debe ser un procedimiento con fines útiles, y no una mera protesta ante el becho consumado".

Edouard Laferrière, Traité de la Juridiction Administrative et des Recours Contentieux, 1896.

\section{INTRODUCCIÓN}

El derecho administrativo cubano, y como parte de él, el control jurisdiccional sobre la administración pública, presenta respecto a los sistemas de derecho administrativo de las más avanzadas sociedades occidentales un retraso de más de cien años, en lo que se refiere al grado de desarrollo y de elaboración teórica y técnico-jurídica, y a su avenencia a la realidad material de la sociedad que pretende regir y cuyas relaciones aspira a regular. Probablemente, uno de los mejores exponentes de esta situación sea el régimen jurídico de la justicia cautelar en el proceso administrativo, el cual está impregnado-como también lo está, en su conjunto, el modelo de control de legalidad de la administración pública en el que él se integra- de las concepciones del iuspublicismo francés y español de la segunda mitad del siglo XIX, dado que la vigente ley sobre proceso administrativo y su régimen cautelar tienen su germen en la Ley española de 13 de septiembre de 1888 .

Por ende, el debate en torno al régimen jurídico de la tutela cautelar en sede de la justicia administrativa está plagado de particularidades y matices. El presente trabajo adopta la siguiente premisa entre sus presupuestos: una lec- 
tura actual de la justicia provisional en sede de lo contencioso-administrativo no debe pasar por alto sus antecedentes históricos, pues son finalmente los fundamentos que aún sostienen nuestro envejecido derecho positivo en este tema. A consecuencia de ello, la temática de la justicia cautelar en sede de lo contencioso-administrativo, por demás, traída a los escenarios en los que vive la sociedad cubana actual, es un tópico rico en complejidades, expresión fidedigna de los retos a los que se enfrentan hoy la ciencia del derecho administrativo en Cuba, sus cosechadores, y sus operadores jurídicos y políticos.

La vigente Ley $\mathrm{n} .{ }^{\circ} 7$, de procedimiento civil, administrativo, laboral (1977) -y posteriormente, económico- (en lo sucesivo, LPCALE), contempla como única medida cautelar a adoptar por el juez, con carácter excepcional, la suspensión de la ejecución del acto administrativo, condicionada al riesgo de producirse daños de imposible o difícil reparación para el ciudadano derivado de la ejecución del acto, y sujeta a que no se produzca con la medida grave lesión al interés público. La justicia cautelar está pensada en la LPCALE como una posibilidad excepcional, como una opción extrema frente al principio general de ejecutividad de las decisiones administrativas, de la misma forma en que la jurisdicción contencioso-administrativa se concibe -desde el propio diseño de la ley, como por la legislación posterior que se ha dedicado poco a poco a restringir las materias que pueden ser objeto de control de legalidad por el juez-, como una jurisdicción singular, es decir, como un cauce de justiciabilidad que no está concebido para ofrecer plenitud jurisdiccional. Pues, así de claro, una tutela cautelar excepcional para una justicia administrativa también excepcional.

Sin embargo, y volviendo a la idea inicial, las transformaciones que urgen para la justicia cautelar en sede del proceso administrativo no vienen avaladas por el impulso de formar parte de los estándares globales de protección judicial de los que informan aquellos derechos más avanzados, cual si de seguir una moda se tratare, o por el mero hecho de decir que formamos parte de una corriente preponderante de desarrollo, aun cuando ese nivel de desarrollo no responda a nuestras necesidades, a nuestras circunstancias ni a nuestras expectativas. Los cambios que se necesitan de cara al régimen cautelar en la jurisdicción contencioso-administrativa se confirman por el hecho de no ser Cuba ajena a los derroteros por los que transita una nación del mundo occidental y del veloz siglo XXI; por ser un país en el que el hecho de construir su Estado bajo un modelo político diferente no lo exime de que su sociedad participe de problemas comunes y padezca de necesidades muy similares a aquellas que perviven en países con un sistema económico diferente, pues al fin y al cabo hemos acogido ciertos paradigmas jurídicos afines, solo que respondemos a problemas similares de forma diferente.

No hace falta ser jurista para saber que la efectividad de la justicia depende, en gran parte, de la rapidez con que se otorgue (Chinchilla Marín, 1999). La ampliación de los márgenes de tutela provisional en sede contencioso-admi- 
nistrativa es una necesidad de nuestros días -si bien no novedosa, pues está presente desde décadas anteriores-, que tiene su argumento fundamental, aunque no el único, en la tardanza de los procesos, es decir, en la dificultad de obtener un pronunciamiento que reconozca y restablezca el derecho lesionado antes de que la sentencia carezca de sentido y utilidad, porque el paso del tiempo ha revertido de forma definitiva la situación material que pensaba proteger. Existe cierto consenso doctrinal alrededor de la idea de que la justicia cautelar es el remedio idóneo para salvaguardar la eficiencia de los pronunciamientos judiciales, que es lo mismo que decir, la eficiencia y la propia razón de ser del aparato judicial. El atasco de asuntos que inunda a los órganos judiciales, la lentitud con la que se tratan los procesos, hace que se ponga en tela de juicio la eficacia de la función judicial, función tan pública como la administrativa. La tutela cautelar se ubica en el terreno de duelo donde se lleva a cabo una lucha entre la preponderancia de la administración pública y su panoplia de prerrogativas, y abrirle paso a los intereses también públicos que se persiguen con una mejora en el ejercicio de la función judicial, con todo lo que ello implica. Las evidencias señalan que se ha terminado escogiendo lo segundo, porque el auge que han adquirido las medidas cautelares para la buena marcha de la justicia administrativa equivale "a garantizar la aplicación real y efectiva de los derechos individuales y sociales, y no solamente proclamar los derechos de todos" (Cappelletti y Garth, 1996, p. 13).

Otros argumentos también nos colocan en dirección del desarrollo estructural y funcional de la tutela cautelar en la justicia administrativa. Las medidas cautelares son un instrumento efectivo de cara a la protección provisional de los derechos mientras se aguarda a la llegada de la decisión de fondo. La Constitución cubana incorpora un abanico de derechos, entre los que se encuentran aquellos comúnmente reconocidos como derechos civiles y políticos, y también una más amplia gama de derechos económicos y sociales; este conjunto de derechos no son otra cosa que el objeto mismo de protección de la tutela cautelar en el campo de la justicia administrativa. Los derechos recogidos en el texto constitucional forman parte esencial del diseño político-jurídico del Estado cubano, y en cuanto tal, su efectiva materialización individual constituye la reafirmación y consolidación cotidiana de ese diseño. Su violación impone al Estado un deber de aseguramiento positivo, una acción encaminada a vencer obstáculos en la senda hacia su concreción, a lo que sin dudas tributaría directamente la justicia provisional, y más aún, su perfeccionamiento. La implementación legal de la tutela cautelar en el proceso administrativo no guarda coherencia con el catálogo de derechos que prevé, en tanto no está concebida como vía eficaz para su protección provisional.

Circunstancia común es también que la sociedad cubana marcha veloz. Los conflictos que se generan en ámbitos como la protección del consumidor, la propiedad intelectual, el urbanismo y la protección del medioambiente, o el derecho de la competencia, requieren de soluciones rápidas porque la espera 
de un dilatado proceso ordinario revertiría de forma definitiva y desfavorable la situación de quien ostenta la razón. El emprendedor que quiere obtener una licencia urbanística para construir un local comercial y se le deniega no puede aguantar los años de espera que transcurren hasta que llega la sentencia del tribunal, porque al cabo de ese tiempo la inflación monetaria ha hecho que la inversión que tenía prevista no sea suficiente, o que las condiciones del mercado hayan cambiado haciendo inviable económicamente su inicial proyecto. Los temas de la justicia cautelar -y de la justicia administrativa en su conjunto- en nuestros tiempos se incardinan en los debates sobre la gobernanza y sobre la buena administración de justicia, dado el impacto sobre lo público de la situación de saturación de los órganos judiciales.

Apostar por transformar positivamente el régimen de justicia cautelar es también proteger la seguridad jurídica como valor de nuestro sistema de derecho $^{2}$. De nada sirve el proceso como institución jurídica si quien interpone la demanda, con apariencia de buen derecho, sigue sometido a la ejecución de la decisión administrativa que está siendo impugnada, y si a la llegada de la sentencia favorable, declarativa del derecho a su favor, la ejecución de este título judicial es materialmente imposible, y ya no tiene ningún valor para el demandante. Es así como pululan ciudadanos cuya situación jurídica real no se aviene a los títulos judiciales legitimadores de derechos que ostentan, existiendo un divorcio entre la realidad de su esfera jurídica y lo que consta en los expedientes judiciales. Es precisamente la seguridad jurídica uno de esos atractivos condimentos que valoran los inversores extranjeros, pues ven en ella mayores garantías en sus proyectos empresariales.

Lo anterior es especialmente significativo para los momentos de cambios por los que transita Cuba, de la mano de un programa de reformas que impulsa el gobierno desde el año 2011, programa denominado "Lineamientos de la política económica y social del Partido y la Revolución" (aprobado por Resolución del Partido Comunista de Cuba). Los lineamientos del Partido y las transformaciones que a su amparo se producen, constituyen una reforma de la administración pública cubana, en sus planos estructural y funcional, y una reforma del modelo económico cubano. En este sentido, lo que nos interesa destacar en esta ocasión es la apertura a la iniciativa económica privada que lleva a cabo este programa de reformas. Nuevos espacios se han abierto para el tráfico iusprivado, y junto a ello, nuevos ámbitos de mercado para invertir y emprender atraen a empresarios nacionales e internacionales. Con ello, nacen nuevos actores económicos. Lo que hace unos años era un escenario marcado por el monopolio estatal en la actividad económica, ahora es un espacio diversificado, donde las relaciones jurídicas no son tan simples como las de antaño,

2 Valor que es resaltado por J. C. PIELOW (2007, p. 266) como fundamento de la tutela judicial pronta y eficaz. 
y donde el Estado debe desempeñar hoy más que nunca su función de ente regulador, ordenador de las nuevas situaciones, de los nuevos actores y de los nuevos intereses involucrados en la construcción de una nueva sociedad. Por el momento, y en lo que a la justicia administrativa respecta, estamos haciendo frente a hechos nuevos con herramientas e ideas de ayer, que difícilmente brindan tutela jurídica óptima a las situaciones y a las relaciones jurídicas de la sociedad cubana del siglo XXI. Sin duda alguna, la justicia cautelar tiene un rol importante que jugar en todo ello. Los objetivos propuestos en este trabajo son la descripción del régimen jurídico de la tutela cautelar en la justicia administrativa en Cuba y los fundamentos teóricos que la nutren, y la formulación de los principios que deben inspirar su perfeccionamiento jurídico.

\section{PANORAMA SOBRE EL RÉGIMEN JURÍDICO DE LA TUTELA CAUTELAR EN LA JUSTICIA ADMINISTRATIVA EN CUBA}

La regulación básica del proceso administrativo se ubica en la LPCALE del artículo 654 a 695 , y dentro de ella, la tutela cautelar toma cuerpo en los artículos 692 a 695. En sede de la jurisdicción contencioso-administrativa, la tutela cautelar se resume en la suspensión de la ejecución del acto administrativo, medida cuya solicitud puede interponerse en cualquier momento del proceso, y se otorgará siempre y cuando con la ejecución se corra el riesgo de ocasionar daños de imposible o difícil reparación al administrado, y de la suspensión no se derive grave lesión al interés público.

El principio de excepcionalidad de la suspensión del acto administrativo rectora, hoy por hoy, el régimen cautelar para la justicia administrativa en Cuba. Su existencia está estrechamente ligada a otro postulado neurálgico de nuestro derecho administrativo: el privilegio de autotutela ejecutiva del que disfrutan los actos de la administración pública. Si como regla general los actos de la Administración son directamente ejecutables desde que se emiten-sobre el fundamento de que la actividad administrativa persigue la obtención de intereses públicos, y que esa finalidad debe conseguirse de forma eficaz-, la consecuencia directa es que la suspensión de la ejecución de sus decisiones sea una medida excepcional, solo otorgable cuando se le ocasionan a la contraparte daños de imposible o difícil reparación, y ello subordinado siempre a que la medida no ocasione perjuicio a los intereses públicos. La regla general para nosotros es la ejecutabilidad inmediata de las decisiones administrativas, y en consecuencia, la excepcionalidad de la suspensión de los actos administrativos.

Sin embargo, de la mano de la LCA (1888) -en tanto hito normativo en el devenir de la jurisdicción contencioso-administrativa en Cuba, y norma fundacional de la tutela cautelar para esta jurisdicción-, la atención debe ser dirigida hacia la también española Ley Reguladora de la Jurisdicción Contencioso- 
Administrativa (1956) (en lo sucesivo LJCA), dado que el grado de similitud en la redacción de los artículos 692 a 695 LPCALE respecto a los artículos 122 a 125 LJCA resulta llamativo. Con un poco más de tres décadas de vigencia de la LPCALE (1977), las semejanzas de nuestra ordenación legal en torno a los presupuesto de concesión de la suspensión del acto administrativo y la regulación prevista por la LJCA no constituyen un punto sobre el que la doctrina cubana, que se ha acercado a los temas del derecho procesal administrativo, haya llamado la atención. Dado el interés en mostrar de forma clara a qué hacemos referencia, reproducimos la parte del articulado que consideramos esencial. Dice el artículo 692 de la LPCA:

El ejercicio de la acción administrativa no impedirá a la Administración ejecutar la disposición general o resolución objeto de la misma, salvo que el Tribunal acordare, a instancia del demandante la suspensión.

Procederá ésta cuando la ejecución hubiere de ocasionar daños o perjuicios de reparación imposible o difícil y siempre que de la misma no pueda derivarse lesión al interés público.

Por su parte, el artículo 122 LJCA establece:

1. La interposición del recurso contencioso-administrativo no impedirá a la Administración ejecutar el acto o la disposición objeto del mismo, salvo que el Tribunal acordare, a instancia del actor, la suspensión.

2. Procederá la suspensión cuando la ejecución hubiese de ocasionar daños o perjuicios de reparación imposible o difícil.

A continuación el artículo 123 LJCA dispone:

1. La suspensión podrá pedirse en cualquier estado del proceso, en primera o segunda instancia, y se sustanciará en pieza separada.

2. Solicitada la suspensión se oirá al Abogado del Estado o representante procesal de la Administración demandada y a las partes demandadas y coadyuvantes, si hubieren comparecido, por término común de cinco días, y si el Abogado del Estado o representante procesal de la Administración demandada se opusiere a la misma, fundado en que de ésta puede seguirse una grave perturbación a los intereses públicos, no podrá el Tribunal acordarla sin que previamente informe el Ministerio o Autoridad de que procediese el acto o disposición del recurso.

Las analogías van desde la propia concepción del modelo cautelar-la suspensión de la resolución administrativa como única medida cautelar, el principio de excepcionalidad que rige como regla para decidir sobre la solicitud de adopción de la medida cautelar, las causales de otorgamiento de la suspensión del 
acto administrativo bajo la fórmula de daños de imposible o difícil reparación, la prevalencia de los intereses públicos sobre la protección cautelar- hasta la redacción misma de los preceptos. No es nuestra intención, sin embargo, acuñar de forma categórica la paternidad de la LPCALE en lo que se refiere a la regulación de la suspensión del acto administrativo, pues estamos frente a una cuestión donde no existen suficientes referencias doctrinales e históricas precedentes de las que asirse para adoptar una postura determinada. Son contados los estudios doctrinales escritos desde Cuba sobre medidas cautelares, y dentro de ellos, son casi inexistentes las referencias a los antecedentes históricos de la actual regulación, por lo que no dimana de ellos mucha luz sobre este particular ${ }^{3}$.

En el afán por descubrir pistas sobre una posible influencia de la LJCA en la redacción del proyecto de LPCALE, tuvimos la oportunidad de acceder a los debates en sede de la Asamblea Nacional para la aprobación del proyecto de la ley, acaecidos en julio de 1977. Sin embargo, la discusión en sede parlamentaria no proporciona pistas al respecto, dado que, en aquel momento, fueron objeto de análisis otros aspectos del proyecto ${ }_{i}^{4}$ sin que tampoco el preámbulo de la

3 Sin la intención de ser exhaustivos, los trabajos sobre la justicia cautelar que integran el acervo jurídico cubano son, fundamentalmente: R. Dolz (1896), Programa de Derecho Procesal Civil, Penal, Canónico y Administrativo y Teoría y práctica de instrumentos públicos, La Habana: Imprenta y Papelería La Universal, De Ruiz y Hermano; A. Del JunCo y André (1949), Derecho Procesal Civil, Segundo curso, La Habana: Imprenta Ucar, García y Cía.; F. ÁlvareZ TAвíO (1954), El proceso contencioso-administrativo. Doctrina, legislación, jurisprudencia, La Habana: Editorial Librería Martí; R. Grillo, G. De Vera y C. R. Grillo (1985), Derecho Procesal Civil II y III, La Habana: Editorial Pueblo y Educación; J. MEndoza Díaz (2007), Un acercamiento al régimen cautelar del proceso económico cubano. Boletín Organización Nacional de Bufetes Colectivos, n. ${ }^{\circ}$ 29, pp. 1-27; I. Pérez GutiérREZ (2010), Del régimen cautelar en el contexto del proceso civil cubano. Tesis presentada en opción al grado científico de Doctor en ciencias jurídicas, La Habana: Facultad de Derecho, Universidad de La Habana, I. Pérez GutiérRez (2012), Lo cautelar en el Proceso Civil cubano. En Panorama del Derecho procesal bispanocubano. Valencia: Tirant lo Blanch, pp. 195-234; y B. MARCHECO ACuÑa (2012), Del régimen de medidas cautelares y de la ejecución de sentencias en el Proceso Administrativo cubano. Panorama del Derecho procesal hispanocubano. Valencia: Tirant lo Blanch, pp. 235-263.

4 Se reproduce, a continuación, el Acta de Primer Período Ordinario de Sesiones de 1977. República de Cuba, Asamblea Nacional del Poder Popular, julio de 1977: "9 de la mañana, del 14 de julio de 1977, se reanuda la sesión iniciada el 12. El Presidente declara el quórum suficiente de 457 diputados para un $95 \%$ del total de diputados. Se le da la palabra a la diputada Marta Lugiayo Delgado, Miembro de la Comisión de Asuntos Constitucionales y Jurídicos de la Asamblea Nacional del Poder Popular, que da lectura al dictamen. Luego de la lectura, el Presidente hace la observación de que el Proyecto de Ley de Procedimiento Civil, Administrativo y Laboral presenta la innovación de que incluye el procedimiento laboral, que hasta ahora no estaba en esta Ley, sino que tenía un rango especial con relación a la justicia laboral. En el orden procesal, el Proyecto plantea que el procedimiento civil común, sobre la declaración oral que estaba establecida en la anterior Ley, se haga por escrito, abreviando el procedimiento; en el orden administrativo la modificación más importante consiste en que la sentencia del Tribunal no puede dictar una resolución admi- 
LPCALE, ya una vez aprobada, proporcione luces. El acervo doctrinal e histórico con que contamos impide avanzar hacia alguna conclusión, e indica mesura a la hora de hacer afirmaciones de tamaña trascendencia. Nos situamos, en todo caso, en el terreno de las conjeturas, aunque tal circunstancia no sea limitativa para apreciar que, así y todo, el mero hecho de la existencia de semejanzas entre ambas disposiciones en materia de tutela cautelar justifica que tanto la doctrina legal como la jurisprudencial del país ibérico, creada bajo el mandato de la LJCA, funja como referencia alternativa para interpretar estos preceptos de la LPCALE y, por qué no, viabilizar la búsqueda de sus fundamentos. En este sentido, sin afán de sentar conclusiones, solo de mostrar esta particularidad, dejamos el debate abierto.

No obstante, ubicar las coordenadas de la regulación sobre medidas cautelares de la jurisdicción administrativa en el sistema jurídico cubano, con vistas a la determinación de sus fundamentos teóricos, exige la toma en consideración de estos y otros aspectos, sin los cuales se puede arribar a una visión no lo suficientemente acabada del asunto. La exigua ordenación legal de la tutela cautelar en la justicia administrativa no responde únicamente a los derroteros del derecho procesal administrativo decimonónico español, sino que debe emplearse una visión de conjunto del estado de desarrollo dogmático del derecho procesal de aquella época, cuya hechura teórica no estaba avocada precisamente a los tópicos de la protección judicial urgente, tal y como es el discurso predominante hoy en sede de tutela judicial cautelar.

nistrativa en sustitución de otra resolución administrativa impugnada. El Tribunal puede declarar en la sentencia la nulidad de esa resolución, pero no dictar otra en su lugar.

"Este proyecto también define mejor aquellas cuestiones administrativas que no pueden ser objeto de impugnación ante los Tribunales.

"En el orden laboral se ha procurado sobre todo, la simplicidad, la sencillez, la fácil comprensión del proceso. Hechas estas observaciones el Presidente pone a discusión el Proyecto en su totalidad.

"El diputado Osvaldo Secé Bonne solicita se le aclare porqué se concede exclusivamente a la Sala de lo Laboral de los Tribunales Provinciales de Ciudad de La Habana la facultad de conocer las reclamaciones contra las resoluciones dictadas por el órgano administrativo supremo en materia de seguridad social. El Presidente le aclara que la razón está en que dicho órgano supremo, el Comité Estatal del Trabajo y la Seguridad Social se encuentra en la provincia Ciudad de La Habana para que no haya conflictos de competencia.

"El diputado Roberto Veiga Menéndez propone que en el artículo 706 entre los requerimientos que deben acompañar a la demanda se agregue el inciso f, donde se le exija constancia de que se tramitó el conflicto laboral en el Comité de Trabajo. Intervienen para aclarar lo propuesto por Veiga los diputados Marta Lugiago Delgado, Carlos Rafael Rodríguez Rodríguez, Fidel Castro Ruz y Osvaldo Dorticós Torrado. Se somete a votación la propuesta y se aprueba por unanimidad agregar el artículo 706 inciso f): resolución correspondiente del Consejo de Trabajo mediante copia autorizada de la misma.

"No existiendo otras propuestas de enmiendas al Proyecto se somete a votación en su totalidad siendo aprobada por unanimidad la Ley de Procedimiento Civil, Administrativo y Laboral a las 10 y 40 de la mañana". 
Si nos remitimos a la jurisdicción civil, la tradicional jurisdicción "ordinaria", la imparcial y protectora por esencia de los derechos e intereses privados en conflicto, vemos que, en Cuba y hasta fecha reciente, la protección cautelar mostraba un grado de elaboración técnico-jurídica inspirada en una normativa española de la segunda mitad siglo XIX. En efecto, la Ley de Enjuiciamiento Civil (1881), hecha extensiva a Cuba en septiembre de 1885 y vigente hasta 1973, constituye la norma en la cual se inspiró el legislador revolucionario para redactar la LPCALE, en lo que a la jurisdicción civil respecta. Los cuerpos procesales nacidos durante el Gobierno revolucionario: la Ley n. ${ }^{\circ} 1261$, de Procedimiento Civil y Administrativo (1974), derogada por la vigente LPCALE, no resultaron beneficiados con una oxigenación de la tutela cautelar, sino que en ambos casos se mantuvo la línea trazada por la vetusta legislación española. Es ilustrativo de esta conclusión el análisis que realiza Mendoza (Mendoza Díaz, 2012).

Bajo el mandato de la LPCALE, el cuadro de la tutela provisional o asegurativa se conformaba por: el embargo de bienes dirigido a asegurar las responsabilidades pecuniarias derivadas de la acción ejercitada (art. 460), el embargo que se podía utilizar en trámite de ejecución de sentencias para garantizar el pago por parte del deudor (art. 476); las medidas provisionales en el proceso de divorcio (art. 385) para disponer de un régimen sobre la guarda y cuidado de los hijos menores mientras duraba la tramitación del proceso; los actos preparatorios del proceso de conocimiento (art. 216) concebidos como diligencias previas a la interposición de la demanda para asegurar el material probatorio que sería empleado en la fase de pruebas ${ }^{5}$; la pensión alimenticia provisional en el proceso sumario para casos de alimentos (art. 369), y las facultades de intervención que el artículo 40 otorga al juez para adoptar cualquier decisión con vistas a asegurar la igualdad de las partes en el debate y evitar situaciones de indefensión. Relación de medidas cautelares que es expuesta por Mendoza (Mendoza Díaz, 2007, pp. 12-13).

Este escuálido escenario vivido por el derecho procesal cubano en materia de tutela cautelar, hasta la primera década del siglo XXI, ha sido resaltado sin cortapisas por nuestra doctrina. El profesor Mendoza no vacila en resaltar:

El Proceso Civil cubano desconoció la existencia de lo que pudiera denominarse como un régimen cautelar, pues se limitó a regular el Embargo como única medida nominada, con la sola finalidad de asegurar las responsabilidades pecuniarias derivadas de la acción ejercitada o que se pretende ejercitar. Esta precariedad

5 Constituyen una modalidad de tutela provisional para PIERO CALAMANDREI, quien las denomina como providencias introductorias anticipadas. Para este autor son aquellas medidas que, en vista de un posible futuro proceso de cognición, tratan de fijar y de conservar ciertas resultancias probatorias, que podrán ser utilizadas después en el proceso (CALAMANDREI, 1936, p. 50). 
normativa marca el panorama doctrinal nacional sobre este tema, que se limita casi exclusivamente al análisis del Embargo (Mendoza Díaz, 2012, p. 12).

En la misma línea se sitúa Pérez Gutiérrez cuando afirma:

Significamos que, con anterioridad, las posibilidades cautelares estaban habitualmente ausentes del panorama procesal patrio y sólo aparecían aislados y dispersos destellos de semejante índole en algunas medidas a las cuales pudiere atribuirse una función asegurativa, lo que no excluye la posibilidad de haberlas utilizado (Pérez Gutiérrez, 2010, p. 55).

La falta de visión de la tutela cautelar como un verdadero régimen jurídico, la inexistencia de una ordenación positiva con enfoque general, y en su lugar, puntuales e inconexos instrumentos de justicia provisional y asegurativa, son las denuncias de estos autores; aspecto que se ve agudizado por el incipiente desarrollo teórico del tema en suelo cubano y por una menguada práctica judicial que no produjo luces y desarrollo al respecto, suceso este último también advertido por ambos profesores.

Con el criterio de la doctrina coincide el Tribunal Supremo cubano, que ha tenido ocasión para pronunciarse sobre la reducida presencia de la justicia cautelar en la LPCALE en la exposición de motivos de la Instrucción 191, de 14 de julio de 2009 (I191/2009). En virtud de esta disposición, se extendió a la jurisdicción civil la aplicación del régimen cautelar creado en su momento para la jurisdicción económica. En aquella oportunidad, el Consejo de Gobierno fundamentó tal decisión bajo los siguientes términos:

La regulación de las medidas cautelares en el procedimiento civil se constriñe en la vigente Ley de Procedimiento Civil, Administrativo, Laboral y Económico al acto preparatorio del proceso de conocimiento de naturaleza cautelar a que se refiere el artículo doscientos dieciséis, apartado segundo; al embargo de bienes regulado en el Libro Segundo, Título Séptimo; así como al embargo provisional en caso de alimentos que prescribe el artículo trescientos sesenta y nueve, párrafo segundo, de dicha ley, lo que deriva en extrema limitación a los efectos del aseguramiento del ulterior cumplimiento de las obligaciones de índole civil declaradas por sentencia firme $e^{6}$.

En esta problemática sigue subyacente el árbol genealógico al que pertenece la LPCALE, pues sus ancestros inmediatos son los cuerpos procesales españoles de la segunda mitad del siglo XIX. Para el derecho procesal decimonónico hispano, la tutela judicial provisional era algo excepcional, casi accidental. Ocupaba poco espacio en los cuerpos procesales civiles y en los manuales de la disciplina, era colocada como instrumento para uso ocasional en manos de los 
jueces, y siempre subordinada o accesoria a un proceso principal. Lo verdaderamente importante era el proceso, y dentro de él, la tipología ordinaria como modelo de los procesos de conocimiento, con sus formas y solemnidades que se concibieron como garantías a las partes, y sus plazos, tiempos y recursos; y junto a los procesos de conocimiento, los ejecutivos, con lo cual se entendía completada de forma satisfactoria la panoplia de herramientas del derecho procesal ${ }^{7}$. La esencia de la Ley de Enjuiciamiento Civil (1885) fue explicada por Tomás y Valiente, de cuya pluma nos servimos para fundamentar nuestra posición en este punto en concreto: "la historia de la codificación del Derecho procesal civil en España -afirma el historiador del Derecho- se caracterizó por el predominio de la tradición del 'solemnis ordo judiciarius' y por el rechazo, consciente o no, de la línea representada por juicios plenarios rápidos" (Tomás y Valiente, 2004, pp. 527-528). En otro párrafo sostiene:

La historia del Derecho procesal civil proporciona a los legisladores españoles (y en general, a los de cualquier país de la Europa continental) dos tipos de procesos civiles: uno era el proceso civil ordinario, basado en la tradición del "solemnis ordo judiciarius", es decir, el proceso construido en la Europa bajomedieval sobre viejos conceptos (como el de la "litis contestatio") [...] El resultado de esta tradición, a la altura de los últimos tiempos del Antiguo Régimen, era un proceso lento, dominado por farragosas distinciones formalistas de los procesalistas teóricos y por los intereses profesionales de una casta de hombres del foro (abogados, jueces, escribanos, relatores...), más inclinados a complicar el proceso en beneficio propio, que a convertirlo en un instrumentos eficaz, rápido y sencillo (Tomás y Valiente, 2004, p. 528).

El eje sobre el cual se construyó la codificación procesal civil española de la segunda mitad del siglo XIX fue el juicio ordinario de mayor cuantía.

Y los senderos por los que marchó la justicia provisional civil por nosotros heredada no resultaron ajenos a la jurisdicción contencioso-administrativa, en lo que a la tutela cautelar respecta. Independientemente de las particularidades de la justicia administrativa (entre las que se encuentran aquellas que atañen

7 Cfr. los comentarios de CHIOVENDA sobre el surgimiento de los procesos sumario y ejecutivo como respuestas a las dilaciones provocadas por el proceso ordinario (CHIOVENDA, 1922, p. 5).

Sobre la historia del derecho procesal y la preeminencia de los procesos declarativos y sus características cfr. también a GOLDSCHMIDT. El autor pone de manifiesto una idea en extremo interesante para comprender los orígenes y causas fundamentales de la justicia provisional. Finalizada la Primera Guerra Mundial, y producto del fenómeno de desvalorización que sufría el dinero, el derecho procesal se vio avocado a acelerar el proceso mediante la implementación normativa de diferentes técnicas. Probablemente, la desvalorización monetaria que se producía durante la sustanciación de los procesos fue uno de los motores de impulsión para la búsqueda de la agilización en la administración de justicia (GOLDSCHMIDT, 2010). 
a su régimen cautelar) derivadas de la especial posición de la administración pública respecto al poder judicial, el estado de desarrollo teórico y las necesidades y circunstancias de la vida misma, que delimitaron la justicia provisional a estrechas fronteras, fueron ingredientes comunes para ambas jurisdicciones. No se logra comprender a cabalidad el régimen jurídico cautelar de la justicia administrativa en Cuba si no se conoce su devenir, y si ese devenir no se enclava en un contexto mayor cual es el de la historia procesal de la justicia cautelar, de la que ella forma parte. Pretender lo contrario tributaría, sin dudas, a alimentar una corriente que parece asomarse en el derecho procesal administrativo cubano: la de entender a la jurisdicción contencioso-administrativa como una jurisdicción especial que exige un tratamiento distinto al de la justicia ordinaria. Sobre este puntual asunto volveremos más adelante.

A la fecha en que se escriben estas páginas, la tutela cautelar en la jurisdicción contencioso-administrativa aún se rige por el privilegio de la excepcionalidad en la suspensión de los actos administrativos, regla que marca la pauta en la acción del juez, quien solo decretará la suspensión del acto administrativo cuando se produzcan daños de difícil o imposible reparación y no se ocasione perjuicios a los intereses públicos.

\section{VIENTOS DE CAMBIOS PARA LA JUSTICIA CAUTELAR CIVIL EN LA PRIMERA DÉCADA DEL PRESENTE SIGLO: EL DECRETO LEY 241/2006}

Los cambios para el derecho procesal cubano arribaron en el segundo lustro de este siglo XXI, de la mano de un decreto-ley que modificó la LPCAL (es a partir de este momento que comienza a llamarse Ley de Procedimiento Civil, Administrativo, Laboral y Económico) para introducir -entre otras cosas- la jurisdicción económica en el diagrama de jurisdicciones que conforma la planta judicial cubana. El Decreto-Ley n. ${ }^{\circ} 241$ (2006) -que a decir de voces autorizadas del ámbito académico cubano fue hecho por jueces y para juecesconstruyó la jurisdicción económica y la equipó con un régimen de medidas cautelares sin precedentes en nuestro derecho patrio. La nueva regulación sobre la tutela provisional dada por el legislador en 2006 se apartó de la regulación monoteísta que hasta ese momento dominaba la concepción misma de la tutela cautelar en el orden positivo en Cuba.

Esta nueva ordenación jurídica sobre la tutela cautelar -eso sí, circunscrita a los conflictos económicos- introdujo una declaración inédita hasta el momento en el derecho cubano: "Todo actor-dice el art. 799 LPCALE- principal o reconvencional, podrá solicitar al Tribunal competente la adopción de medida cautelar". A diferencia del esquema de jurisdicción contencioso-administrativa basado en el privilegio de ejecutividad de los actos administrativos, los juicios económicos se benefician de una declaración genérica sobre la posibilidad 
en manos de las partes en el proceso de solicitar tutela cautelar; $;$ y que, a diferencia de la jurisdicción civil, no restringe el objeto de la tutela cautelar al embargo de bienes para satisfacer responsabilidades pecuniarias o la pensión alimenticia provisional.

Las novedades no hacen más que empezar. En armonía con la declaración sobre el uso general y común de la tutela cautelar en el proceso, la ley apodera al juez con la facultad de adoptar la medida cautelar que considere adecuada para el caso concreto. Luego de una lista con carácter ejemplificativo, establecida en el artículo 803 LPCALE, se deja al arbitrio del tribunal la adopción de aquella medida cautelar que asegure la eficacia del proceso.

La regla general en nuestro derecho -salvo la excepción dispuesta para los procesos civiles en el embargo de bienes que comentaremos luego- era que la medida cautelar podía solicitarse en cualquier momento del proceso, desde la fase inicial junto con la presentación de la demanda o durante la tramitación del asunto. Así está previsto también para el proceso contencioso-administrativo. "La suspensión podrá pedirse en cualquier estado del proceso -dispone el artículo 693 LPCALE- y se sustanciará en pieza separada". Sucede que el proceso administrativo se inicia con la presentación de la demanda (art. 674 LPCALE), no se prevén trámites previos como suele haber en el derecho comparado. Para la jurisdicción civil, la solicitud de embargo de bienes podía solicitarse junto con la presentación de la demanda, o en cualquier momento posterior (art. 461 LPCALE), salvo que la acción se ejercitare contra una persona que se hallase ausente o pretendiere ausentarse del país, o que pudiese presumirse que trataría de hacer desaparecer u ocultar sus bienes (art. 4462.2 LPCALE), en cuyo caso podía solicitarse la medida cautelar de embargo de bienes previo a la interposición de la demanda (art. 461 LPCALE).

Sin embargo, El DL 241 (2006) da pasos significativos en pos de hacer uso extensivo de las potencialidades de la tutela cautelar de cara a la protección judicial efectiva, al introducir la tutela cautelarísima. "La medida cautelar establece el artículo 801 LPCALE- podrá solicitarse antes de o al interponer la demanda principal, o en cualquier momento posterior durante el proceso". El artículo 805 LPCALE prevé que a la interposición de medida cautelar se dé traslado a la contraparte por tres días y se celebre audiencia, diligencia a la que el tribunal citará a las partes, en el que serán oídas y resuelto sin ulterior trámite la solicitud cautelar. Junto a esta tramitación "ordinaria" del incidente cautelar, el legislador introdujo una regulación hasta entonces insólita para el ordenamiento jurídico cubano: la posibilidad de solicitar medida cautelar sin que el tribunal disponga la celebración de la vista, es decir, la posibilidad de obtener inmediatamente la protección cautelar del juez inaudita parte sin que a la parte afectada se le dé traslado y sea escuchada (art. 805 LPCALE).

No obstante, las buenas nuevas del DL 241 (2006) no llegaron a la regulación de las causales de otorgamiento de las medidas cautelares de la misma forma, o con la misma intensidad, con que vemos irrumpieron en otros aspectos del 
régimen cautelar. Procede la adopción de la medida cautelar cuando "concurran circunstancias debidamente acreditadas, que evidencien el riesgo cierto de daño irreparable para la parte actora de no adoptarse la misma". Si se trata del aseguramiento de obligaciones de pago se exigirá además prueba documental de la que pueda inferirse la existencia cierta y actual de la deuda. En todo caso, el Tribunal deberá valorar los perjuicios que pueda ocasionársele al demandado o a terceros, así como la conducta previa de las partes. Para cada uno de los presupuestos de otorgamiento nos remitimos al artículo 804 LPCALE. Por la trascendencia que posee el tema de las presupuestos de otorgamiento de las medidas cautelares dentro de los objetivos planteados en este estudio, será objeto de desarrollo en el próximo epígrafe dedicado a los fundamentos para una modificación del régimen cautelar en la jurisdicción contenciosoadministrativa en Cuba. Baste por el momento dejar sentado la modificación que en este punto introdujo el DL 241 (2006), para continuar describiendo lo que ha acontecido en el orden positivo en Cuba en materia de tutela cautelar y llegar al estado del tema a la fecha en que se escriben estas páginas.

Los favorables vientos de cambios continuaron oxigenando el panorama de la justicia cautelar para el derecho cubano. Casi tres años después de la publicación del DL 241 (2006), el Consejo de Gobierno del Tribunal Supremo Popular de Cuba extiende la aplicación del régimen de medidas cautelares implantado para la jurisdicción económica a la civil, mediante la I191 (2009). A partir del 1. ${ }^{\circ}$ de junio de 2009 los jueces de la jurisdicción civil cuentan con lo que debe considerarse para el derecho procesal de la Isla como un régimen cautelar, por primera vez reglado como tal.

A la nueva ordenación legal de la tutela cautelar para los órdenes civil y económico le sucedieron críticas por parte de la doctrina. Han sido objeto de señalamiento insuficiencias técnicas, problemas derivados de la mimética articulación de tal régimen al seno de la justicia civil, e incoherencias de jerarquía normativa respecto a materia que debió haber sido objeto de regulación por disposición de rango superior con vocación de generalidad y permanencia (Pérez Gutiérrez, 2010, p. 60). Cierto también es -y en ello todos parecen estar contestes- que la nueva ordenación jurídica de la tutela cautelar para los órdenes civil y económico constituye un salto cualitativo respecto al estado de cosas en nuestro derecho previo a la entrega en vigor del DL 241 (2006), impulso que coloca al derecho procesal civil cubano en las cercanías de los estándares contemporáneos de protección judicial cautelar.

La nueva regulación cautelar no tiene cabida hasta estos momentos para la justicia administrativa. Por expreso mandato del Tribunal Supremo, la jurisdicción contencioso-administrativa no se ha visto beneficiada de la extensión que en 2009 recibió el orden civil. El apartado tercero de la I191 (2009) es bien claro, cuando ordena: "Los tribunales de la jurisdicción civil aplicarán en lo pertinente, además de las normas que en tal sentido específicamente les conciernen, las regulaciones contenidas en la Cuarta Parte, Capítulo X, artí- 
culos 799 al 810, de la Ley de Procedimiento Civil, Administrativo, Laboral y Económico, en lo referido al embargo de bienes y otras medidas cautelares, a los efectos de asegurar de manera eficaz el ulterior cumplimiento de las obligaciones de índole civil decretadas por sentencia firme" ${ }^{\prime \prime}$.

Los motivos por los cuales el Tribunal Supremo, en ocasión de promulgar la I191 (2009), excluyó a la justicia administrativa del ámbito de aplicación del nuevo régimen cautelar no formaron parte de la exposición de motivos de la aludida disposición. Se desconoce si el Consejo de Gobierno del Tribunal Supremo valoró en algún momento la extensión del régimen cautelar a la jurisdicción contencioso-administrativa, en caso afirmativo, se no se conocen los argumentos que se manejaron para ignorar la aplicación de este "beneficio" a un cauce de solución de conflictos que nuestro ordenamiento jurídico ubica en el mismo estatus que se le atribuye a la jurisdicción civil.

En este sentido, llama la atención que la I191 (2009) rompe con una línea de actuación sostenida por el Tribunal Supremo dos años antes, cuando dictó la Instrucción n. ${ }^{\circ} 186$ (2007) (en adelante I186 [2007]). Esta disposición añade, a lo ya contenido en la LPCALE, una nueva regulación sobre el tema de la ejecución de sentencias, en dirección a proporcionar un conjunto de reglas más claras y precisas que las contenidas en los preceptos de la citada ley para cada supuesto condenatorio. En esta oportunidad, el ámbito de aplicación de la nueva ordenación jurídica sobre la ejecución de sentencias se incorporó a las jurisdicciones civil y contencioso-administrativa, con lo cual el régimen de ejecución de sentencias es homogéneo para ambos cauces jurisdiccionales.

Lo sorprendente es que en aquella oportunidad, la introducción de nuevas reglas para la ejecución de las resoluciones judiciales se fundamentó en motivos muy similares a los que se esgrimieron dos años después para la aplicación del régimen cautelar a los procesos civiles, aspecto que intensifica las incógnitas y polémica en torno al tema. La exposición de motivos de la I186 (2007) explica los fundamentos que impulsaron a la modificación de la LPCALE en lo que a las reglas de ejecución de las resoluciones judiciales respecta. En el primer Por Cuanto se sostiene: "El cumplimiento de la ejecución de una sentencia constituye la materialización del éxito de la pretensión deducida por la persona interesada en los procesos civiles y administrativos ${ }^{9}$ en que reclama la satisfacción de algún derecho...". El segundo Por Cuanto continúa la explicación:

8 Con amparo en el artículo 121 de la Constitución cubana (1976), el Consejo de Gobierno del Tribunal Supremo Popular dicta normas de obligatorio cumplimiento para todos los tribunales, e imparte instrucciones sobre la base de la experiencia de estos para establecer una práctica judicial uniforme en la interpretación y aplicación de la ley. La I191 (2009) es una disposición dictada en virtud de esa habilitación constitucional.

El resaltado es nuestro. 
A pesar de que el propio cuerpo legal en los preceptos subsiguientes se encarga de establecer la forma de actuar del órgano jurisdiccional en los diferentes supuestos que ello requiera, en ocasiones se ha incurrido en deficiencias que de alguna forma han entorpecido dicho trámite, lo cual evidencia la necesidad de adoptar precisiones en tal sentido. En el Dictamen aprobado por la Asamblea Nacional -dice el Por Cuanto tercero-con motivo de Rendición de Cuentas que el Sistema de Tribunales ofreció a la misma en fecha veintinueve de junio de 2007, se hizo indicación acerca de la necesidad de implementar medidas que tributen a alcanzar la ejecución de las decisiones judiciales, como fórmula necesaria para la materialización del derecho reconocido a favor de persona natural o jurídica ${ }^{10}$ interesada en los procesos ventilados en la vía jurisdiccional.

Por su parte, y a los efectos de mostrar a qué hacemos referencia, desde una perspectiva comparativa reproducimos el fragmento esencial de la controvertida disposición de 2009. La I191 (2009) fundamenta la extensión del régimen cautelar del proceso económico a los procesos civiles en la necesidad de -y se cita textualmente- "asegurar de manera eficaz el ulterior cumplimiento de las obligaciones de índole civil decretadas por sentencia firme".

Para garantizar la eficacia en el cumplimiento de la resolución judicial se identifican dos caminos a seguir: perfeccionar los regímenes de ejecución de sentencia y de tutela cautelar, sin que sea excluyente uno de otro, pues al contrario, solo con la acción conjunta de ambos se transitará con éxito por el camino de la eficacia de nuestras resoluciones judiciales. Así, se modifica el régimen de ejecución de sentencias para los órdenes civil y contenciosoadministrativo; no obstante, y a pesar de ser un objetivo común para ambas jurisdicciones -identificado por la Asamblea Nacional como problemática a eliminar-, la tarea se haya incompleta, pues solo se articula un nuevo régimen cautelar para la jurisdicción civil y se mantiene la tutela cautelar en la justicia administrativa perteneciente a los orígenes fundacionales del derecho administrativo franco-español, muy alejado de las circunstancias socio-económicas de la sociedad cubana actual, de sus demandas de protección judicial rápida y de los estándares de desarrollo teórico por los que discurre el derecho procesal administrativo contemporáneo.

Los peligros van más allá de la desventaja en que se halla la justicia administrativa respecto a sus homólogos civil y económico para garantizar la eficacia de sus pronunciamientos -lo cual de por sí es asunto de tamaña trascendencia-. La implantación de un moderno régimen cautelar para las jurisdicciones económica y civil fue negada para el proceso administrativo, que continúa con un obsoleto modelo de tutela provisional; y por tanto, establecida está una distinta protección cautelar para los derechos de los ciudadanos cuando litigan en la jurisdicción civil que para cuando lo hacen en la contencioso-administrativa. 
Esta situación, apartada de la línea seguida por la I186 (2007), se traduce en una diferencia de "trato" que lanza una llamada de alerta, desde los concisos marcos de la tutela cautelar, sobre una posible consideración y tratamiento de la jurisdicción contencioso-administrativa como una jurisdicción "especial", distinta del tronco ordinario.

Desde la perspectiva orgánica o estructural, no hace daño recordar que el principio de unidad de jurisdicción constituye un postulado rector de nuestra organización judicial, cuyo reconocimiento positivo se inicia en el texto constitucional. La primera parte del artículo 120 de la Constitución (1976) deposita el ejercicio de la función judicial en el Tribunal Supremo Popular y en los demás tribunales que la ley instituye. La articulación normativa de la unidad de jurisdicción continúa cuando la primera parte del artículo 121 de nuestra norma fundamental proclama la condición de sistema del grupo de órganos judiciales y su independencia funcional. "Los tribunales constituyen un sistema de órganos estatales -dice el citado precepto-, estructurado con independencia funcional de cualquier otro y subordinado jerárquicamente a la Asamblea Nacional del Poder Popular y al Consejo de Estado". Ese sistema de órganos estatales, cuya función es la impartición de justicia, está integrado -a tenor del artículo 3 de la Ley n. ${ }^{\circ}$ 82, De los Tribunales Populares (1997)por: el Tribunal Supremo Popular, los Tribunales Provinciales Populares, los Tribunales Municipales Populares, y los Tribunales Militares.

La organización estructural y funcional del cuerpo de tribunales de nuestro país, de cara a la articulación de la unidad de fuero, sigue su construcción con la competencia atribuida al Consejo de Gobierno del Tribunal Supremo para emitir instrucciones de carácter obligatorio hacia el resto de los órganos judiciales, con el fin de establecer una práctica judicial uniforme en la interpretación y aplicación de la ley (tercer párrafo del artículo 121 de la Constitución). El marco positivo general para la implementación del postulado de la unidad de jurisdicción se cierra con la relación de Salas que integran el Tribunal Supremo Popular y los Tribunales Provinciales Populares (cfr. arts. 23 y 32, respectivamente, de la Ley 82 [1997]), entre las que figura la jurisdicción contencioso-administrativa atribuida, junto a la jurisdicción civil, a las Salas de lo Civil y lo Administrativo.

Si bien consideramos saludable hacer referencia a la posición de la jurisdicción contencioso-administrativa dentro del aparato judicial cubano, para no olvidar su condición de jurisdicción ordinaria similar al resto de las que integran la Administración de justicia en la Isla, también es importante mirar hacia la parte "sustantiva" de la problemática planteada por la innovación del régimen cautelar de dos jurisdicciones sin que alcanzara a los predios de la justicia administrativa. Cierto es que antes de la instauración del nuevo régimen de tutela cautelar, las medidas provisionales de la jurisdicción civil diferían del modelo cautelar previsto para el proceso administrativo. Pero las distancias que separaban a ambas regulaciones se debieron a los particulares 
condicionamientos histórico-jurídicos sobre los que se construyó el modelo de justicia administrativa que Cuba heredó, tópico sobre lo que ya hemos apuntado los elementos generales.

Cierto también es que desde décadas atrás la ciencia del derecho procesal administrativo contemporáneo viene propiciando un cambio en este sentido. El derecho comparado de muchos países, incluso de algunos pertenecientes a nuestro mismo sistema de derecho administrativo, ha incorporado una concepción de la tutela cautelar en sede contencioso-administrativa que desecha la regla de la excepcionalidad de la suspensión del acto y acoge el principio de los efectos suspensivos de la interposición de la solicitud de medida cautelar, e incluso los efectos suspensivos del establecimiento de la demanda como postulado general ${ }^{11}$. Se ha ampliado la panoplia de medidas cautelares y los márgenes de actuación del juez para adoptar aquella que considere adecuada para el caso concreto, y se prescinde de la fórmula de producción de daños de imposible reparación así como del tópico de la ponderación del interés público como causales para el otorgamiento de la medida cautelar, sustituyéndolas por las condiciones que fungen para los procesos civiles, entre otros aspectos ${ }^{12}$. En esta línea, las muy particulares reglas sobre las que se erigía la justicia cautelar en los procesos administrativos le han dado paso a un proceso gradual de homogeneización respecto a las que priman para la jurisdicción civil, desechando las prerrogativas de la administración pública en pos de asegurar el propio sentido de la Administración de justicia. Pero sobre este punto volveremos en el próximo acápite por constituir parte de los propios fundamentos que pueden valorarse para una innovación de la tutela cautelar en sede administrativa. Es suficiente por el momento curarnos en salud y dejar sentada la improcedencia

11 Así ocurre en el derecho alemán. La Ley de la Jurisdicción Contencioso-Administrativa (1960) determina que la interposición del recurso provoca la suspensión de los efectos de la decisión administrativa; al respecto cfr. MAURER (2011).

12 En Venezuela, la Ley Orgánica de la Jurisdicción Contencioso-Administrativa (2010) apertrecha al juez con la clásica suspensión del acto administrativo junto a la posibilidad de otorgar todo tipo de medida de urgencia necesaria para el caso. Los presupuestos de otorgamiento son: el periculum in mora, la apariencia de buen derecho, y la ponderación con el interés público presente. Un estudio comparativo de esta nueva ley venezolana en MATA MARCANO (2010).

El derecho argentino prevé la posibilidad de establecer medidas cautelares autónomas por el juez a petición de la parte, estando todavía en trámite de agotamiento de la vía administrativa. Sobre esta interesante solución cfr. MAQUES BATTAGLIA y MATíaS SAC (2012). En el derecho mexicano, los jueces también cuentan la fórmula de las medidas cautelares positivas y una regulación más flexible de los requisitos para su concesión. Véase directamente en la Ley Federal de Procedimiento Contencioso-Administrativo (2005).

La Ley española 29/1998, reguladora de la Jurisdicción Contencioso-Administrativa, incorpora el sistema de numerus apertus de las medidas cautelares. Los presupuestos para la concesión de la medida cautelar son: el peligro en la demora y la ponderación de los intereses en conflicto. La finalidad de la tutela cautelar es garantizar la futura ejecución de la resolución judicial. 
de excluir a la jurisdicción contencioso-administrativa de una modificación sustancial, tal y como se ha hecho entre los años 2006 y 2009, del régimen jurídico de la tutela cautelar si se esgrimen los fundamento de la especialidad de esta jurisdicción o del derecho aplicable, o de la administración pública como parte de la relación procesal. La jurisdicción contencioso-administrativa no está exenta de particularidades, propias y derivadas del derecho que en ella se aplica: el administrativo, pero esos rasgos distintivos pueden coexistir pacíficamente con una formulación común de principios generales de la tutela cautelar ${ }^{13}$, y de hecho así lo hacen ${ }^{14}$.

\section{FUNDAMENTOS PARA UNA REFORMA DE LA TUTELA CAUTELAR EN LA JURISDICCIÓN CONTENCIOSO- ADMINISTRATIVA}

\section{Proceso y tRanscurso del tiempo}

Una idea de Alcalá-Zamora y Castillo -esgrimida mirando a la justificación de la institución del proceso- resulta traspolable a los terrenos de la justicia cautelar para comprender el que es uno de sus fundamentos básicos: "el proceso no surge del proceso - dice el autor-, sino de una situación extra y meta procesal, que él está llamado a canalizar y resolver" (Alcalá-Zamora y Castillo, 2000, p. 12).

Pues la institución cautelar también tiene como punto de partida una situación meta procesal, presente desde tiempos inmemoriales, tal parásito del derecho procesal: la dilación misma del proceso desde que se interpone la demanda hasta que se obtiene el pronunciamiento de fondo puede provocar en cambio en la situación jurídica del demandante que haga el pronunciamiento inservible, y su ejecución totalmente ineficaz, dado que el caso requería de pronta solución para garantizar la dación de justicia. Por ello, explica Calamandrei: "la función de las providencias cautelares nace de la relación que se establece entre dos términos: la necesidad de que la providencia, para ser prácticamente eficaz, se dicte sin retardo, y la falta de actitud del proceso ordinario para crear sin retardo una providencia definitiva" (Calamendri, 1936, p. 43).

13 Para Cuba, homogeneizar el régimen cautelar administrativo con el civil es parte de un proceso iniciado en el siglo XX de igualación de la jurisdicción contencioso-administrativa a la justicia ordinaria, porque los fundamentos que avalaron en su momento la instauración de una única medida cautelar para el contencioso fueron los mismos sobre los cuales se construyó en su momento a la jurisdicción contenciosa como una jurisdicción especial, con reglas distintas a la justicia ordinaria que favorecían a la Administración.

14 La extensión de las construcciones del derecho procesal común hacia la Administración pública es un proceso dado en Argentina, que GORDILLO resalta, percibiéndolo como muestra de progreso (GORDILLO, 2006, pp. XIII-31). 
Las medidas cautelares nacen como solución a una problemática práctica bien concreta: la tardanza de los procesos, la demora en la obtención de un pronunciamiento judicial de fondo, y las consecuencias negativas derivadas de esa tardanza tanto para el actor como para el Estado. Esa situación de excesiva demora en la obtención de los pronunciamientos judiciales -y hablamos de años a la espera de una sentencia- fue calificada por Calamandrei a la altura de 1935 como "el más antiguo y el más difícil problema práctico de toda legislación procesal" (Calamendri, 1936, p. 43). Tres años antes, la doctrina y el derecho positivo alemanes tenía bien claro los requisitos que debían cumplirse para que procediera la adopción de medida cautelar. Se enfatizaba que para el éxito del embargo de bienes y el resto de las medidas provisionales de seguridad debe concurrir una causa o motivación, consistente en la existencia de una circunstancia justificativa que amenace con la variación de la situación y vuelva imposible o dificulte de forma grave la realización de la acción o la ejecución del título jurídico (Goldschmidt, 2010, p. 563).

La denuncia del autor italiano devela que la tardanza en la procura de pronunciamiento judicial no es una problemática novedosa, sin embargo, la connotación del tema se ha multiplicado con creces en las sociedades actuales, siendo un tema especialmente sensible para muchos Estados contemporáneos. La masificación de la justicia ha demostrado que la demora en la obtención de sentencia es, más allá de un presupuesto para la concesión de la medida cautelar, el fundamento y razón misma de la justicia cautelar. A día de hoy, el atolladero en que se hallan muchos de nuestros juzgados continúa siendo el presupuesto fáctico que ha catapultado el desarrollo teórico de las medidas cautelares, y de la justicia de urgencia en su conjunto, hacia altos estándares de protección judicial de los que hace gala lo más avanzado del derecho procesal contemporáneo. La "justicia de masas" a la que se enfrentan los actuales Estados, la situación de asfixia en la que se sitúan los tribunales debido a la cantidad de demandas que entran continuamente, ha acentuado un proceso de creación de nuevos instrumentos, junto al perfeccionamiento y ampliación de otros ya existentes (como las mismas medidas cautelares), cual alternativa a la espera de una resolución de fondo, alternativa que se traduce en la administración de una "justicia provisional", con la cual se logra equilibrar la situación real de la que parte el demandante y garantizar la eficacia de la resolución final mientras se espera por ella, dejando la "justicia definitiva", cuando ya se puede aguardar por ella, a los largos y dilatados procesos ${ }^{15}$.

15 Cfr. una explicación sobre la justicia provisional en el derecho francés en LAFERRIÈRE (2007, p. 191).

Cfr. los comentarios que al respecto hace García DE ENTERRía sobre los ordenamientos jurídicos de aquellos países europeos que contemplan llamativas técnicas de justicia provisional (GARCíA DE ENTERRía, 2006, p. 434). 
La demora en la obtención de una resolución sobre el fondo del asunto derivó en uno de los principios capitales sobre los que se articula la teoría de las medidas cautelares: el periculum in mora, cuya traducción al español es peligro en la demora. Este postulado constituye uno de los presupuestos que deben cumplirse para que proceda la adopción de una medida cautelar. Su formulación se asocia a la producción de un daño inminente y jurídico o a la urgencia en la obtención de una decisión provisional que, a la espera de la definitiva, garantice la efectividad de aquella (Chiovenda, 1922, pp. 261-263). Es preciso "que a causa del peligro la providencia solicitada tenga el carácter de urgencia" (Calamandrei, 1936, p. 41), en cuyo caso, de no adoptar la medida cautelar, se vería disminuida o anulada la finalidad de la sentencia. Es decir, se está en presencia del peligro en la demora cuando existe posibilidad de daño por el retardo de la sentencia, siendo la mora de la resolución final en sí misma la causa de un posible daño ulterior, o la propia situación de hecho en la que se halla el demandante lo que exige con urgencia una decisión judicial a su problema. La tutela cautelar se dirige a contrarrestar la producción de lesión jurídica por la tardanza en la obtención de una resolución final. La formulación de Calamandrei plantea la interpretación del peligro en la demora como la pérdida de la finalidad del recurso; es precisamente el tiempo que tarda en llegar la sentencia la causa directa de la producción del perjuicio o daño para el demandante y del menoscabo de la efectividad de la resolución final.

La dilación de los procesos judiciales y el aumento de demandas ante los juzgados resultaron factores de impulso para el desarrollo de la justicia cautelar; sin embargo, otros aspectos terminan de esculpir el cuadro de circunstancias que han colocado a la tutela provisional en los círculos de debates sobre la eficacia de la justicia en los contemporáneos Estados de Derecho. La atención se traslada hacia el ordenamiento jurídico como elemento que puede convertirse en elemento favorecedor del "abuso de los procesos" y correlativas desventajas procesales o sustantivas; ; como resultado, el proceso sufre un fenómeno de desnaturalización, convirtiéndose en un obstáculo para la supervivencia de la justicia.

Si miramos a quién asigna el ordenamiento la carga de accionar, vemos que es el propietario quien debe correr con la interposición de la demanda y esperar a un largo y dilatado proceso judicial para lograr el reconocimiento de su derecho a reivindicar su bien de quien lo haya estado detentando. En igual situación se encuentra el acreedor respecto al deudor, a quien le corresponde la carga de interponer un dilatado proceso declarativo para hacerse del reconocimiento del derecho, mientras el deudor se beneficia del período de tiempo que dura el proceso sin pagar, y se perjudica el acreedor, quien

Una lectura latinoamericana, específicamente, argentina, sobre la justicia de urgencia en BRUNO DOS SANTOS (2012, p. 347). 
sufre irremediablemente la devaluación monetaria durante todo el tiempo que transcurre hasta que llega a la ejecución forzosa de la obligación. En similar posición se halla el responsable civilmente, y a todos, en su condición de accionantes, les corresponder la cargar de la prueba sobre los hechos que aleguen. Deudor, poseedor y el responsable civilmente tienen en el proceso la escapatoria para alargar el cumplimiento de sus obligaciones. A ello añadimos que los problemas de la judicatura en Cuba despliegan su manto sobre la demora en la obtención del pronunciamiento declarativo, y pasan luego por el aro del trámite de ejecución y sus consabidas dificultades prácticas. García de Enterría ha sentenciado esta situación con las siguientes palabras:

El proceso está, con frecuencia, aunque esto suene extrañamente, positivamente estimulado por las Leyes, para que los deudores puedan no pagar o pagar menos de lo que deben. En un enorme número de casos (yo me permito creer que quizá en la mayoría), el proceso se ha convertido en un instrumento de la injusticia, no de la justicia, aunque la expresión pueda sonar extrañamente. Es una perversión del sistema procesal, sin duda alguna (García de Enterría, 2006, p. 429).

La dilatada espera deviene en una cómoda posición para quien no le urge la llegada de una resolución judicial que amenaza con cambiar el statu quo de una situación que le beneficia, situación cuyo sostenimiento puede ser alargado aún más mediante el uso de los medios de impugnación disponibles para ello, en detrimento de aquel que tiene la razón y no le queda otra opción que esperar. Ante la abierta posibilidad de abusar de los procesos para alargar el escenario de espera y frustrar la obtención de tutela judicial a la otra parte, ante la inherente demora de los procesos, cabe preguntarse qué utilidad tiene como cauce jurisdiccional, como expresión de una función estatal, y como espacio creado por el Estado con la finalidad de obtener una resolución justa a través de un cauce igualmente justo.

Esta situación dio surgimiento a un postulado de creación doctrinal, cuyos orígenes se remontan a la doctrina procesalista italiana, específicamente en las obras de Chiovenda (1922) y Calamandrei (1936), y que años después, en la última década del pasado siglo XX, de la mano del Tribunal de Justicia de la Unión Europea, se ha convertido en un auténtico principio general del derecho sobre cuya base se ha visto perfeccionada la dogmática de la justicia cautelar. Hacemos referencia al principio general del derecho que proclama: "La necesidad de servirse del proceso para conseguir la razón no debe convertirse en daño para quien tiene razón", postulado que ha devenido en uno de los presupuestos esenciales para el otorgamiento de la tutela provisional. Fue rescatado de estas obras doctrinales por el Tribunal Constitucional italiano en una sentencia de 25 de junio de 1985, para identificar en él el principio de la igualdad y declarar aplicable al contencioso-administrativo el precepto de la Ley del Proceso Civil que establecía una cláusula general y abierta de medidas 
cautelares. Posteriormente el rescate definitivo se produjo en junio de 1990, cuando el entonces Tribunal de Justicia de las Comunidades Europeas dictó sentencia en un caso conocido como Factortame, decisión que introdujo en el ordenamiento comunitario europeo la facultad de los jueces de los países de la Unión de suspender la aplicación de una ley nacional para proteger derechos invocados sobre la base del derecho de la Unión.

El principio constituye una prolongación del periculum in mora, viene a complementarlo, a confirmarlo y consagrarlo como postulado esencial dentro de la teoría de la justicia cautelar. Su finalidad es la misma, garantizar la plena eficacia de la decisión jurisdiccional mediante el arbitrio de medidas provisionales que permitan conservar el sentido de una futura sentencia. "Un verdadero e inequívoco principio general del Derecho" -calificado así por García de Enterría (2006, p. 212) - que se yergue como pauta de interpretación normativa, pero que también es el resultado de la articulación jurídica de una realidad práctica que le precedía. Es, como dice el profesor español, un principio general del derecho de naturaleza hermenéutica y ontológica ${ }^{16}$.

Los principios de peligro en la demora y el proceso como no obstáculo para quien tiene la razón son el resultado de optar, primero, por la operatividad del aparato judicial, y segundo, por comprender el papel central de la institución cautelar para asegurar la efectividad de la tutela judicial. En resumidas cuentas, estos postulados son consecuencia de la relación existente entre la efectividad de la justicia y tutela cautelar, en tanto la segunda tributa directamente al logro de la primera. Por ello, la doctrina parece estar conteste en que la razón de ser de las medidas cautelares es la de aminorar los efectos negativos de la espera de la sentencia, garantizar la eficacia del pronunciamiento cuando sea que este llegue, y restablecer el equilibrio de las partes en el proceso. Parece una idea clara, fácil y ligera de comprender, sin embargo, se le pueden sacar otras capas en profundidad, más allá de las que afloran en la superficie. ¿Qué significa garantizar la eficacia de la sentencia? ¿Qué trascendencia tiene el que los fallos de los órganos judiciales sean eficaces? En primer lugar, se apuesta por la justicia cautelar como instrumento sin el cual no es posible (en aquellos casos que así lo requieran) proteger judicialmente los derechos e intereses de los particulares, toda vez que, en muchos casos, solo mediante un adecuado sistema de medidas cautelares es que puede protegerse de forma efectiva los derechos fundamentales reconocidos en el ordenamiento jurídico. El protagonismo que ha ganado la tutela provisional en las actuales "jurisdicciones de masas", donde solo una actuación rápida puede asegurar la protección del derecho lesionado hasta que se decida sobre el fondo del asunto, demuestra que la verdadera tutela de las situaciones jurídicas de los ciudadanos depende

16 Recogido en el ordenamiento jurídico español en la Ley 1/2000, de 7 de enero, de Enjuiciamiento Civil. 
de un bien articulado régimen de justicia cautelar que permita aguardar por la decisión final, para que esa resolución sobre el fondo no sea dictada en vano, sino que sirva de algo. En muchos casos, las medidas cautelares son la única alternativa para la protección judicial de los derechos de los ciudadanos, pues sin ellas la posterior sentencia poco o nada podría hacer en defensa de quien tiene la razón. Dicho de otra manera, sin medidas cautelares la tutela judicial corre el riesgo de convertirse en un espejismo, en un sitio donde se emiten pronunciamientos retóricos que poco solucionan y restablecen. Búsquese las medidas cautelares si se desea una real y eficaz protección de las situaciones jurídicas de los particulares que se hallan reconocidas en el orden positivo, pues con ellas podemos darnos el lujo de aguardar la llegada de la sentencia declarativa de fondo.

En segundo lugar, porque ser la clave que asegura la eficacia de los pronunciamientos judiciales, apostar por el perfeccionamiento y ampliación del régimen cautelar, significa la inclinación de la balanza a favor de la eficacia de la función jurisdiccional, de la credibilidad en los órganos judiciales y de la eficacia del orden jurídico vigente, en detrimento de otros poderes como los de la Administración, y de la creencia casi irracional en la necesariedad de sus prerrogativas. En numerosos casos son las medidas cautelares las que garantizan la eficacia de la función jurisdiccional, pues con ellas se procura restablecer el equilibrio, conservar la situación en un estado de cosas de forma tal que la futura sentencia no se dictará en balde, cuando ya no haya remedio para el aquejo del demandado, sino que será de utilidad. Si estamos de acuerdo con que "la función jurisdiccional es una actividad que tiene por objeto asegurar la conservación del orden jurídico existente" (Carré de Malberg, 2000, p. 636), se comprenderá que la función de la justicia cautelar en las actuales sociedades -dado el importante rol que han pasado a desempeñar en las últimas décadaslas coloca en el epicentro del éxito, credibilidad y utilidad del aparato judicial del Estado, por ser este quien controla y restablece la legalidad. De la tutela cautelar depende en muchos casos el honor de la justicia, tanto más como la eficacia formal y material de nuestras leyes.

El uso de la tutela cautelar como regla en el caso de la justicia administrativa es una clara toma de posición a favor de la función judicial y, correlativamente, una disminución de la relevancia de los poderes de la Administración, básicamente, de la prerrogativa sin tregua de la ejecutabilidad de sus actos. La ampliación del ámbito funcional de las medidas cautelares en la jurisdicción contencioso-administrativa es un sí a la eficacia del sistema judicial, un voto a favor del control de legalidad de la actuación administrativa y más concretamente del control de legalidad de la actividad de ejecución de los actos administrativos, que de no adoptarse la medida cautelar solo se realizaría en el acto de enjuiciamiento final, es decir, en sentencia. La balanza se inclina a favor del poder judicial, de garantizar la buena marcha de la función jurisdiccional y de sus decisiones finales, de garantizar la eficacia del aparato 
coactivo del Estado a costa de un retroceso de la exorbitante posición de la Administración. Para Pacteau, el auge de la tutela cautelar en la jurisdicción contencioso-administrativa ha sido:

... la gran innovación de este juicio en el siglo XXI al servicio de la eficacia del juez administrativo. Y que, desde ese momento, ha abierto reales expectativas de reforzamiento de los derechos, como igualmente ha contribuido a cambiar la imagen del juez administrativo por encima de ser considerado un juez que anula o repara y que ahora realmente salvaguarda y protege. Después de la caída del poder discrecional de la Administración en el siglo XX, es casi el poder administrativo mismo el que es puesto en cuestión en beneficio del poder jurisdiccional (Pacteau, 2005, p. 319).

Como consecuencia de ello, la finalidad misma de la institución cautelar ha dado un giro. No se trata de evitar, con la suspensión del acto administrativo, la producción de daños o perjuicios de reparación imposible o difícil al demandante (criterio de nuestra LPCALE), sino de garantizar la utilidad misma de la decisión jurisdiccional. Se trata de ampliar los márgenes de la tutela cautelar para que actúe cuando exista el riesgo de producirse daños de difícil o imposible reparación, pero también cuando se dé riesgo de todo tipo de daño, dada la situación de urgencia en la que se halla el actor, si eso implica que una posterior sentencia favorable será inútil restablecedora de su derecho. Que la larga duración de los procesos deriva en riesgo de producción de una situación irreversible, con lo cual la tutela cautelar será lo que garantice que la sentencia tenga una incidencia real en la esfera jurídica del que reclama logrando una reparación verdadera.

\section{El VALOR DE LAS APARIENCIAS EN EL DERECHO}

No es suficiente la presencia del periculum in mora para aprobar una solicitud de constitución de medida cautelar. La justicia provisional tutela, precisamente, a aquel que acredite un daño en sus derechos e intereses por el paso del tiempo hasta la llegada de la sentencia, si y solo si, se vislumbra que puede ser luego el efectivo titular de ese derecho. Es decir, la justicia cautelar no protege a quien, habiendo interpuesto demanda y corriendo el peligro de producción de un daño por el transcurso del tiempo que tarda en finalizar el proceso, no demuestra seriedad en su petición. Es necesario que, junto al peligro en la demora, la posterior sentencia pueda ser favorable a la pretensión de quien la solicita, o lo que es lo mismo, que la demanda cuente con una apariencia de buen derecho o humo de buen derecho (Chinchilla Marín, 1999, p. 56) -al que se identifica con el clásico tecnicismo de fumus boni iuris-. La adopción de una medida cautelar se basa en un conocimiento periférico o superficial del derecho alegado que indica la probabilidad de existencia del derecho discutido; se trata de un juicio preliminar favorable realizado por el juez sobre los motivos y fundamento de la demanda (Santamaría Pastor, 2010, p. 1277). 
De ello deriva que no sea condición sine qua non para la valoración del fumus la aportación de prueba fehaciente sobre la que se funda el derecho. Resulta incorrecto -bajos los presupuestos teóricos de este principio- exigir al actor en el trámite de medida cautelar que demuestre de forma irrefutable que tiene la razón en lo que pide. Eso corresponde al fondo del asunto, debe ser valorado en sentencia luego de la práctica de todo el material probatorio aportado por las partes. De lo que se trata en el incidente cautelar es de determinar las posibilidades de éxito de la demanda con base en los elementos que se aportan y se alegan por las partes en esa fase inicial del proceso. Se debe pedir una prueba indiciaria sobre el fundamento de su situación jurídica cautelable, y no una prueba indubitada del derecho que pretende se le proteja, pues de lo que se trata es de proteger aquellas situaciones que por su buena apariencia jurídica deban ser beneficiadas con tutela provisional anticipada.

Llevado al seno de la justicia administrativa, el principio del fumus conserva su núcleo conceptual común, no sin que se le aderece con ciertas particularidades. La especial condición de la Administración pública como parte en el proceso, su particular posición respecto a los órganos judiciales y los administrados, y las reglas derivadas del propio objeto de esta jurisdicción, es decir, del control de legalidad a posteriori de un catálogo de modalidades de acción pública, hacen que el ámbito de aplicación del humo de buen derecho se amplíe para abarcar toda actitud arbitraria de la Administración desde la propia decisión que se impugna hasta posturas asumidas en fase de recurso administrativo y luego en el proceso.

La apariencia de buen derecho en los terrenos de la jurisdicción contencioso-administrativa pasa -como señala García de Enterría-, por "la consistencia aparente de los títulos que invoca el recurrente como, de manera especialmente relevante, con la falta de seriedad en la respuesta de la Administración" (García de Enterría, 1991, p. 7). El fumus o humo de buen derecho de una pretensión puede ser valorado tanto en sentido positivo como negativo para arribar a la conclusión de su existencia. Es decir, una pretensión con apariencia de legitimidad es aquella que está avalada con algún pronunciamiento administrativo previo que le ampara, o aquella situación en la que no se vislumbra una franca y radical ilegalidad. En todo caso, la contrapartida a una pretensión con apariencia de legitimidad es una actuación administrativa con aspecto de ilegalidad o arbitrariedad. Será protegible la situación jurídica del demandante cuando la actividad administrativa impugnada presente indicios de irregularidad.

Como venimos anunciando, la apariencia de buen derecho no solo opera frente a la concreta acción administrativa que es objeto de inconformidad de la demanda, el producto acabado vulnerador de la situación jurídica del administrado. El fumus extiende su ámbito de aplicación hacia determinadas posturas asumidas por la Administración en el seno mismo de la contienda, que evidencian posiciones arbitrarias y abuso de su posición privilegiada. La apariencia de buen derecho engrosa su contenido al incluir bajo su manto la 
valoración sobre la actitud de la Administración ante el proceso y los abusos que hace de ella. En este sentido, el silencio administrativo es especialmente valorado como un elemento más en la concesión de la medida cautelar ${ }^{17}$. La falta de respuesta de la Administración a los argumentos esgrimidos por el particular no debe pasar inadvertida para el juez en la ponderación sobre la solicitud de tutela cautelar, pues la ausencia de pronunciamiento administrativo frente a solicitudes o recursos (que, no olvidemos, es el incumplimiento de una obligación legal) debe ponderarse como un eventual abuso de la autotutela administrativa. El silencio administrativo en materia de medidas cautelares se identifica como abuso del privilegio de la autotutela administrativa pues es el camino que toma la Administración para desdeñar y no atender a las reclamaciones de los particulares, actitud que puede adoptar como consecuencia de la especial posición que le cubre respecto a los administrados. En aquellos casos en que se dé mediando solicitud de medida cautelar debe ser un elemento más a tomar en cuenta, indiciario de una situación de irregularidad o arbitrariedad administrativa, o de un uso desviado del proceso.

Asumir el silencio administrativo como indiciario de un abuso del privilegio de autotutela implica que otras posiciones de la Administración, como la no contestación a la solicitud de medida cautelar, o la no entrega del expediente administrativo, sean datos tendentes a justificar la adopción de la tutela cautelar. No basta con ponderar la seriedad de los argumentos de la demanda, junto a la apariencia de buen derecho, la actitud de la Administración debe ser un elemento a valorar para que se acceda a la justicia provisional. Una oposición poco seria o el abuso de la Administración de sus ventajas posicionales son elementos indiciarios para que se justifique la tutela cautelar del demandante. Con el análisis preliminar de los argumentos del actor y de la acción administrativa objeto de impugnación se determina la existencia del humo o apariencia de buen derecho. A través de la valoración de las actitudes de la Administración es posible establecer el fumus de arbitrariedad o abuso de la posición de autotutela y acceder a la solicitud de tutela cautelar para proteger las situaciones jurídicas de los particulares y para corregir las acciones administrativas viciadas de ilegalidad y arbitrariedad.

Visto desde otra perspectiva, por medio de la tutela cautelar se pone coto a la pervivencia de situaciones administrativas antijurídicas y a su ejecución, en tanto la decisión cautelar frena la ejecución de aquellos actos viciados de ilegalidad ${ }^{18}$. A través de la jurisdicción contencioso-administrativa se someten

17 Esta ha sido la toma de postura asumida por el Tribunal Supremo español en un trascendental auto de 17 de enero de 1991.

18 En el derecho comunitario europeo una de las condiciones de otorgamiento de la medida cautelar es que existan dudas sobre la validez del acto administrativo impugnado. Así se dejó sentado por el Tribunal de Justicia de la Unión Europea en la sentencia Zuckerfabrik (1991), y posteriormente ratificado en la sentencia Atlanta (1995). 
a control de juridicidad las actuaciones de la Administración pública luego de que, transcurrida una prolongada espera, se obtiene el pronunciamiento de fondo que sanea la situación jurídica del demandante. Mientras se aguarda por la llegada de esa decisión, la situación jurídica del actor puede empeorar porque la Administración puede darle ejecución a su acto (o porque el conflicto, derivado de otro tipo de acción administrativa, se agrava con el mero transcurso del tiempo). Es decir, a través de la justicia cautelar los jueces pueden controlar no solo la legalidad de la actividad administrativa sino también el ejercicio de la potestad de ejecución de los actos de la Administración.

\section{Prerrogativa de ejecutividad de los actos administrativos VERSUS JUSTICIA CAUTELAR}

La dogmática toda de la tutela cautelar constituye un bandicap para el privilegio de ejecutividad de las decisiones administrativas. El principio de ejecutividad de los actos administrativos supone que dichos actos son inmediatamente eficaces, y que su impugnación no determina por sí sola adopción de medida para aminorar o suspender sus efectos, todo ello bajo los fundamentos de la necesariedad de la ejecución continuada de la actividad administrativa sin obstáculos en la producción de sus efectos para satisfacer los intereses comunes. La adopción de medida cautelar contra la decisión ejecutoria solo procedía en supuestos absolutamente excepcionales. Por ende, no es difícil reconocer que, a consecuencia de la teoría sobre la justicia provisional, se generasen cambios en el régimen de la prerrogativa de ejecutividad de las decisiones administrativas, pues los presupuestos de adopción de las medidas cautelares parece que no casan muy bien con la regla general del privilegio de decisión ejecutoria, o que al menos exigen su replanteamiento (Parada Vázquez, 1968; Santamaría Pastor, 1983).

Enervar la regla de la ejecutividad de los actos administrativos no es un tema novedoso en el debate científico. Los cambios que se han pedido y argumentado en este sentido datan de la segunda mitad del siglo XX y llegan a nuestros días, y su plasmación efectiva a nivel positivo también. A finales de los años 60 del pasado siglo -en un trabajo que provocó el inicio de una famosa y nutritiva polémica doctrinal en razón de los rasgos esenciales de la justicia administrativa en España-, Parada Vázquez calificaría el sistema de justicia administrativa de ese país bajo los siguientes términos: "sistema cuya premisa esencial es que el oponente de la Administración ha de llegar al proceso en la posición de vencido... y ejecutariado, pues a diferencia de la apelación civil, la interposición del recurso contencioso no suspende la ejecución del acto administrativo recurrido". Más adelante diría: "Ni que decir tiene que este sistema [...] protege muy cómoda y eficazmente la actividad del Estado, la legal y la ilegal, la justa y la injusta" (Parada Vázquez, 1968, p. 67). 
De la mano de críticas sobre las consecuencias de la prerrogativa de ejecutividad de los actos administrativos y el correlativo carácter revisor de la jurisdicción contencioso-administrativa, no faltan comentarios sobre los fundamentos iusfilosóficos que se adentran en la esencia y razón de ser misma de este modelo de justicia administrativa de corte francés. Sistema de justicia administrativa francesa sobre el que François Julien Laferrière, haciendo alusión a las recientes leyes de 1995 y 2000, resume en los siguientes términos: "Hace muy poco tiempo [...] que el juez administrativo francés tiene la posibilidad de enfrentar de manera satisfactoria las situaciones de urgencia. Antes se oponían a su intervención eficaz los principios derivados de la antigua tradición de soberanía del Estado y de omnipotencia de la administración, heredada de la monarquía borbónica y del imperio napoleónico" (Laferrière, 2007, p. 207).

Autores como Santamaría Pastor han puesto de manifiesto que esta regla es reflejo de la raíz autoritaria del derecho administrativo francés, y que en la fecha en que surgió fue "correlato del papel predominante y primordial asignado a las nociones de soberanía y poder en la caracterización del Estado" (Santamaría Pastor, 1983, p. 1611), debido a la generalización de las ideas de poder y dominación como fundamento de los Estados europeos de finales del siglo XIX, y a la retracción que ello significó para las garantías judiciales de protección de derechos.

El dogma inexorable de la no suspensión de los actos administrativos que, no olvidemos, trajo causa de la particular interpretación del principio revolucionario francés de separación entre la Administración y la Justicia- ha cedido el paso a la plenitud jurisdiccional de la tutela cautelar como vía para garantizar el derecho fundamental a la tutela judicial efectiva y el interés por la salvaguarda de la utilidad y eficacia de los fallos judiciales. Baste dar una ojeada al panorama comparado para advertir el sentido de los cambios que se han estado dando en esta dirección así como sus fundamentos en los valores o premisas que acabamos de señalar.

A raíz de la Constitución de España de 1978, en especial de su artículo 24 que recoge el derecho de todos los ciudadanos a la tutela judicial efectiva, una nutrida jurisprudencia española logró consolidar la limitación de la regla de la no suspensión del acto administrativo (que no es eliminación) dado su enfrentamiento con el derecho a la tutela judicial efectiva, derecho de carácter fundamental ${ }^{19}$. En 1985, el Tribunal Constitucional italiano declaró inconstitucional la limitación de la suspensión del acto administrativo como única medida cautelar prevista frente a las decisiones de la Administración; en consecuencia se habilitó sobre la base del fumus o apariencia de buen derecho la adopción de medidas cautelares positivas. En 1990, el Tribunal de Justicia de

19 Remitimos al comentario que hiciese de las sentencias del Tribunal Supremo español dictadas en 1982 (SANTAMARÍA PASTOR, 1982, p. 1611). 
las Comunidades Europeas definió la obligación de los jueces nacionales de suspender cautelarmente su propio derecho nacional (tanto normas como actos administrativos) cuando fuesen en contra del derecho comunitario, habilitando a la adopción de medidas positivas, todo sobre la base del fumus y del derecho a la tutela judicial efectiva $-\mathrm{y}$ aun cuando ese derecho no estuviese recogido de forma expresa en los tratados ni en las normas de derecho comunitario-. Esta doctrina se había iniciado un año antes, con un auto del propio Tribunal dictado en el seno del mismo caso, y posteriormente ratificada en 1990 en un caso en el que se debatía la validez de una ley alemana. En el año 1988, Francia dictó el Decreto de 2 de septiembre en virtud del cual extiende al campo de la jurisdicción contencioso-administrativa la técnica del référé-provision que ya existía para la jurisdicción civil. Con esta medida se crea un proceso incidental que tiene como objeto el cobro anticipado de deudas contra la Administración antes de que se dicte sentencia declarativa en el proceso principal. Posteriormente, la Ley de 30 de junio, sobre medidas cautelares ante las jurisdicciones administrativas, extiende a la justicia administrativa todo el repertorio de medidas cautelares que ya existían para la jurisdicción civil. Los motivos de esta nueva regulación descansan en lograr una más abierta y operativa jurisdicción contencioso-administrativa, de forma que quede definitivamente igualada a la civil, y en el derecho a la tutela judicial efectiva, que implica un mandato para el Estado francés derivado de la firma del Convenio Europeo de Derechos Humanos. En el derecho alemán se ha invertido el privilegio de no suspensión de los actos administrativos. La regla es ahora el efecto suspensivo de los actos administrativos con interposición de la demanda, cuyo fundamento descansa en el derecho a obtener tutela judicial frente a las vulneraciones de los poderes públicos, recogido en el artículo 19.4 de la Ley Fundamental de Bonn.

Pero la amplitud y fuerza que ha tomado el tópico de la tutela cautelar se enmarca en una corriente mayor que impulsa un cambio sustancial en la forma de entender el contencioso-administrativo. Junto a la construcción teórica de los presupuestos de concesión de la tutela cautelar-que no es más que la otra cara de la moneda de la flexibilización de la regla de no suspensión de los actos de la Administración- se aboga en general por no dejar margen posible a los espacios de acción pública inmunes al control de legalidad. Los pasos que se han dado en defensa de la subjetivización del recurso por exceso de poder, de una interpretación cada vez más reducida de la categoría acto de gobierno, de comprender que la discrecionalidad administrativa es una actuación que discurre entre límites jurídicos, por construir la doctrina de los conceptos jurídicos indeterminados para acotar los márgenes de decisión pública, o por declarar que la actividad de ejecución de las sentencias dictadas en procesos contenciosos-administrativos es también parte de la función jurisdiccional y afinar su régimen jurídico, persiguen todos la misma finalidad: dotar de plenitud jurisdiccional al contencioso-administrativo, implantar un cambio de paradigma, divorciarse de los estrechos márgenes en los que se concibió hace 
unos dos siglos aproximadamente en su consideración de un cauce excepcional y singular, para ocupar el lugar que le corresponde -al nivel del que ocupa la jurisdicción civil-y desempeñar el papel de protectora de los derechos e intereses de los ciudadanos en tanto instrumento de control y restablecimiento de la legalidad de la actividad de la Administración pública y eje central de lo que se pretende sea un Estado de derecho ${ }^{20}$.

La operatividad alcanzada por las medidas cautelares no significa la muerte del régimen de autotutela administrativa, ni mucho menos. La formulación de la justicia cautelar bajo estos términos no toca a la autotutela declarativa, como tampoco se pone en tela de juicio la ejecutividad y ejecutoriedad de los actos administrativos, sino solo una manifestación concreta de este privilegio: el efecto no suspensivo de sus decisiones, quedando al margen de la controversia otras expresiones de esta cualidad. Y es que no se pone en duda la validez del fundamento de esta prerrogativa, que descansa en la necesidad de no paralizar la ejecución de la actividad administrativa so pena del peligro potencial que podría acarrear para los intereses o las necesidades públicas su paralización. Sin embargo, lo que se viene a cuestionar con la dogmática de la justicia cautelar es la condición de la no suspensión de los actos administrativos como regla indiscutible, cuando son muchos los casos en que la interrupción de los efectos jurídicos de la actividad administrativa no trae necesariamente perjuicios al interés público, ni mucho menos limitaciones al buen funcionamiento de la Administración. "Como muchas veces ocurre-dice Santamaría Pastor-, los problemas de las instituciones jurídicas no provienen de su existencia, sino de su generalización: el mantenimiento del privilegio de no suspensión es absurdo en todo caso por el carácter universal que hoy posee" (Santamaría Pastor, 1983, p. 1615). La ejecutividad se antoja necesaria ahí donde sería realmente peligrosa para el interés público la suspensión del acto, pero se devela como innecesaria ante situaciones en las que se vuelve incluso contra la propia finalidad del proceso, o cuando la ejecución de la decisión crea situaciones irreversibles o de difícil reparabilidad. De lo que se trata es de comprender que la no suspensión de las decisiones administrativas no es una regla con utilidad fija, sino que lo que debe plantearse es cuándo es comprensible la suspensión y en qué casos no, cuestión sobre la que arroja luz, precisamente, la teoría de las medidas cautelares.

En esta misma línea se sitúa Barcelona Llop, autor que recuerda que el fundamento de la ejecutividad de los actos administrativos, esto es, la necesidad de servir con eficacia a los intereses generales, es una cláusula general abstracta que obliga a verificar en cada caso que la ejecutividad sea puesta en tela de juicio con cada solicitud de medida cautelar (Barcelona Llop, 1995, p. 158). El contenido de la operación iría a verificar si en el caso concreto procede soste- 
ner la ejecución de la decisión administrativa porque así lo demanda el interés general, o si procede adoptar la medida cautelar para preservar la efectividad de la sentencia y evitar que el tiempo que tarde en llegar la sentencia haga inútil el proceso y el pronunciamiento judicial final. La idea que se intenta transmitir es que el acto administrativo no tiene por qué representar siempre un interés general que deba prevalecer de forma automática ${ }_{i}$ la presencia del interés general debe demostrarse cuando el destinatario se opone a las pretensiones de la Administración.

En consecuencia con todo lo anterior, es pacífica la admisión, e incluso necesidad, de desprenderse de la hegemonía de la suspensión de la ejecución del acto administrativo como única medida cautelar en la jurisdicción contencioso-administrativa. Los argumentos que se barajan por la ciencia del derecho procesal administrativo para fundamentar la atribución al juez de medidas cautelares positivas no difieren de aquellos que se esgrimen para otorgarle protagonismo a la justicia cautelar; son básicamente los mismos, y en este sentido, explicarlos sería reproducir lo ya expuesto.

Para el caso de Cuba el tópico exige que se tomen en cuenta ciertas particularidades derivadas del grado de desarrollo que posee la justicia administrativa en su conjunto, toda vez que el proceso administrativo se construye sobre la clásica concepción del "proceso al acto". La actividad administrativa impugnable ante la jurisdicción contencioso-administrativa se limita a los reglamentos y actos administrativos -incluida la inactividad formal o silencio negativo-, sin que sean objeto de control de legalidad las ya tradicionales tipologías de la acción pública que reconoce el derecho comparado, como la vía de hecho y la inactividad material ${ }^{21}$. Si en el derecho comparado el enriquecimiento del catálogo de medidas cautelares sucedió por un cauce natural y consecuente con una primera ampliación de las modalidades de actividad administrativa que podían ser objeto de revisión judicial, en nuestro caso aún tenemos pendiente ese primer paso, con lo cual en estos momentos nos encontramos ante la emergencia no de uno, sino de dos cambios sustanciales de la jurisdicción contencioso-administrativa.

\section{EL ORDEN POSITIVO EN CUBA PROVEE DE RECURSOS PARA UNA INTERPRETACIÓN PRO TUTELA CAUTELAR}

Las transformaciones que urgen para el régimen cautelar del contenciosoadministrativo no deben ser vistas como la necesidad de sustituir una pieza por otra, manteniendo intacta esa maquinaria que es la jurisdicción contencioso-

21 Para obtener mayor información sobre la actividad administrativa que puede ser objeto de impugnación en la jurisdicción contencioso-administrativa en Cuba cfr. PEREIRA BASANTA (2012). 
administrativa. Plantearse las disfuncionalidades y formular propuestas de reordenación de nuestro modelo cautelar debe hacerse desde la comprensión de su pertenencia a un tópico mayor, cual es la reformulación sustancial que se exige de nuestro contencioso-administrativo, tema en donde la justicia cautelar constituye parte esencial de ese todo a modificar. Es decir, lo que necesita verdaderamente el régimen de tutela cautelar del proceso contencioso-administrativo es una transformación sustancial de los principios que le informan, de los presupuestos de concesión y de la diversificación de las medidas cautelares en manos de los jueces; reordenación que debería estar integrada, so pena de caer en disfuncionalidades o anomalías técnico-jurídicas -como puede ser, por ejemplo, que nuestro contencioso es solamente revisor de dos tipos de actuación administrativa: el acto y el reglamento, por lo que incorporar una gama de medidas positivas exigiría ampliar el diapasón de modalidades de acción pública que pueden someterse al control judicial de legalidad- dentro de una reformulación de nuestro modelo de justicia administrativa ${ }^{22}$.

Conscientes de que esa sería la vía de solución a los males que en estos terrenos aquejan al derecho administrativo cubano, y sabiendo que ello solo es posible mediante una acción de tipo legislativo, con todos los posibles impulsos doctrinales y jurisprudenciales que le puedan anteceder, pero una operación normativa al fin, dedicamos el presente epígrafe a resaltar aquellos puntos del orden positivo que a día de hoy, y siendo el régimen cautelar el que es, son tributarias de una interpretación algo más benévola para la suspensión del acto administrativo. $\mathrm{Si}$, como vemos, la decisión sobre la solicitud de medida cautelar en el contencioso-administrativo es básicamente una cuestión de ponderación entre los intereses privados y públicos que convergen sobre la decisión administrativa, haremos referencia a los elementos del ordenamiento jurídico que devienen favorables para una apertura de la justicia cautelar, que no son más que los recursos que el orden positivo coloca al alcance de nuestras manos y que pueden facilitar una interpretación progresista que -más allá de los estrechos marcos del artículo 692 LPCALE- contribuyen a obtener la finalidad de la justicia cautelar: asegurar la eficacia de la ulterior sentencia.

La regulación de la tutela cautelar en el proceso contencioso-administrativo actúa como un corsé para la justicia provisional. De la forma que está formulado el régimen cautelar en la LPCALE son muy limitadas las posibilidades de ser beneficiado con la adopción de la medida, y nula la concesión de una de carácter positivo. Aun peor, si la suspensión de la ejecución de acto solo procede ante la producción de daños de difícil o imposible reparación (y haciendo además la salvedad de que deberá pasar por el filtro del análisis sobre la producción de lesión al interés público), la institución del proceso administrativo corre

22 Propuestas de reformas del proceso contencioso-administrativo han sido esgrimidas por Arias Gayoso (2008), Marcheco Acuña (2009) y Pereira Basanta (2012). 
el riesgo de convertirse -dada la lentitud propia de este tipo de trámite- en la causa y origen mismo de situaciones jurídicamente lesivas de la esfera jurídica del ciudadano que tiene la razón, dada la obligatoriedad de someterse a un proceso judicial para obtener el reconocimiento de su derecho, la ejecutividad que por regla general tienen las decisiones administrativas y la posibilidad de atención a su solicitud de tutela cautelar únicamente ante daños de imposible o difícil reparación. El proceso contencioso-administrativo es un productor de posteriores títulos jurídicos que legitiman posibles reclamaciones por responsabilidad pública, porque la tutela cautelar no tiene permitido extender su manto para prevenir el surgimiento de aquellas lesiones a la esfera individual que puedan ser fácilmente reparables.

El escenario, aunque sombrío, tanto por el sistema que adoptó la LPCALE como por la expresa decisión del Tribunal Supremo cubano de no hacer partícipe a la justicia administrativa del régimen cautelar de las jurisdicciones civil y económica, cuenta con espacios en los que el ordenamiento jurídico parece ser intransigente respecto a una apertura de la funcionalidad de la tutela cautelar (como es el propio art. 692 LPCALE), y también con zonas de luz donde los preceptos aguardan a ser utilizados para defender la ampliación del ámbito de acción de la justicia provisional.

Una de esas zonas oscuras -además de las ya analizadas- es advertida por Mendoza Díaz cuando afirma: "La Constitución cubana no consagra el derecho de acción dentro del catálogo de los derechos fundamentales, por lo que es inútil hurgar en la búsqueda de asidero constitucional a una tutela cautelar derivada de la función jurisdiccional" (Mendoza Díaz, 2007, p. 3). El no reconocer el derecho a la tutela judicial efectiva, o un genérico derecho de acción o protección judicial, priva a la justicia cautelar de beneficiarse del rango normativo de la Constitución, y de la garantía de poder extraer de aquella incorporación algún contenido cierto y esencial, sellado a modificaciones legales. La tutela cautelar no forma parte de la panoplia de derechos de abolengo constitucional, es una institución de mera configuración legal que no cuenta con un núcleo duro del cual asirse para su posterior articulación técnico-jurídica.

La Constitución, sin embargo, proporciona otras pautas. El artículo 10 refrenda el principio de legalidad en los siguientes términos: "Todos los órganos del Estado, sus dirigentes, funcionarios y empleados, actúan dentro de los límites de sus respectivas competencias y tienen la obligación de observar estrictamente la legalidad socialista y velar por su respeto en la vida de toda la sociedad". El mandato de respecto a la ley se alza como un fundamento político, social y económico del Estado cubano, porque se ubica en el Capítulo I que toma ese nombre, es decir, un principio que rige el funcionamiento del aparato estatal y el sistema de derecho del país, "lo que puede traducirse -explica Matilla Correa- en que formalmente va más allá de construir una idea directriz de necesario cumplimiento para el adecuado desarrollo de la vida estatal, para erigirse en fundamento político de esa vida, arista ésta que 
nuevamente cualifica su existencia y acentúa su repercusión jurídica" (Matilla Correa, 2003, p. 115).

El mandato de legalidad funge como una garantía jurídica fundamental para la existencia misma y el pleno ejercicio de los derechos de los ciudadanos, así como el deber de respeto que impone para los órganos estatales. La protección de los derechos y de las situaciones jurídicas de los ciudadanos, ahí donde proceda porque la norma así lo establece, es ejecución de la ley. Al amparo del principio de legalidad, procedería una solicitud de medida cautelar en la que mediara apariencia de buen derecho y peligro en la demora, es decir, riesgo de que, por el paso del tiempo hasta la finalización del proceso, la decisión judicial deviniese ineficaz, en un pronunciamiento sin sentido o utilidad, con lo cual la decisión judicial, que al mismo tiempo es realización y ejecución de la legalidad, no se cumple por llegar tarde. Durante las primeras décadas posteriores al triunfo del Gobierno revolucionario en 1959 hasta la postrimería del siglo XX, fue unánime la doctrina cubana en considerar que los pronunciamientos judiciales no implicaban actividad de creación jurídica alguna, sino que eran mera ejecución de la ley (Garcini Guerra, 1986) ${ }^{23}$; las decisiones judiciales se consideran, básicamente, actos de ejecución de la legalidad socialista, con lo cual las medidas cautelares, en tanto instrumentos que se dirigen a garantizar la ulterior eficacia de las sentencias, constituyen herramientas para la aplicación del principio de legalidad. La tutela cautelar es también ejecución del derecho, con lo que en los supuestos en que los mandatos de la ley pudiesen llegar tarde para restablecer las relaciones jurídicas sería prudente rescatar el significado y valor constitucional del principio de legalidad en el ejercicio de ponderación de adopción de tutela cautelar, pues está claro que la mera aplicación del artículo 692 LPCALE no le garantiza cien por cien.

Desde el preámbulo de la Constitución se establece que el valor que persigue el texto fundamental y la República que ella crea es el culto a la dignidad plena del hombre. Esta directriz vuelve a reproducirse en el artículo 9, cuando atribuye al Estado cubano el deber de "garantizar la libertad y la dignidad plena del hombre, el disfrute de sus derechos, el ejercicio y cumplimiento de sus deberes y el desarrollo integral de su personalidad". El artículo 1 de la norma fundamental también coloca a la protección y respecto de los derechos individuales como una de las directrices del Estado cubano, al proclamar: "Cuba es un Estado socialista de trabajadores, independiente y soberano, organizado con todos y para el bien de todos, como república unitaria y democrática, para el disfrute de la libertad política, la justicia social, el bienestar individual y colectivo y la solidaridad humana".

23 Este autor despegó en este período revolucionario como el administrativista más destacado autor del manual de derecho administrativo que se referencia, el que a día de hoy constituye la bibliografía básica de esta asignatura en la carrera universitaria de licenciatura en derecho en el país. 
Por tanto, la protección de los derechos no es una mera consecuencia de su reconocimiento positivo cuya realización se entrega al interés privado, sino uno de los fines para los cuales de constituye el Estado; la salvaguarda de los derechos de los ciudadanos es un fin de interés público, una de las bases deontológicas del Estado cubano, y como finalidad pública que es, debe tener su espacio en la valoración sobre su protección cautelar (Carrasco Casí, 2006). Si, al amparo de la LPCALE, el juez administrativo debe ponderar entre los intereses públicos y privados al momento de acceder a la suspensión del acto administrativo, la relación que siempre parece presentársenos como dicotómica en realidad no es tan obvia como se nos hace ver, máxime cuando las titularidades privadas que se defienden presentan una apariencia de buen derecho y la actividad administrativa aparece con tintes de ilegalidad o arbitrariedad. La protección de los derechos de los ciudadanos es también un fin de interés público. Esta idea parecer ser ratificada por Cuba con la firma, en febrero de 2008, del Pacto Internacional de Derechos Civiles y Políticos (1966), pendiente de ratificación. El artículo 2.3 a) del texto internacional establece: "Cada uno de los Estados Partes en el presente Pacto se compromete a garantizar que: a) Toda persona cuyos derechos o libertades reconocidos en el presente Pacto hayan sido violados podrá interponer un recurso efectivo, aun cuando tal violación hubiera sido cometida por personas que actuaban en ejercicio de sus funciones oficiales".

El texto constitucional vuelve a facilitar el fortalecimiento de la tutela judicial administrativa, esta vez por la falta de pronunciamientos expresos. El principio de autotutela administrativa, y sus distintas manifestaciones, no participa de las bases constitucionales del derecho administrativo cubano, como tampoco cuenta con una posterior formulación legal. En el derecho administrativo cubano, los actos administrativos producen efectos desde la fecha en que se dictan, son inmediatamente ejecutivos, y la interposición de recurso contencioso-administrativo no suspende su ejecución; sin embargo, salvo la tercera de estas reglas, las dos primeras no cuentan con un expreso reconocimiento legal. Si nos apegamos a razones estrictamente positivas, la autotutela declarativa y el privilegio de ejecutividad de los actos administrativos surgen a consecuencia, precisamente, de la regulación del proceso contenciosoadministrativo de la LPCALE, y no como una cualidad o condición intrínseca del acto administrativo llevada al orden normativo, pues tampoco contamos con regulación dedicada a ordenar las bases jurídicas de la categoría acto administrativo. El régimen de autotutela administrativa, y como manifestación de él, el privilegio de ejecutividad de las decisiones de la Administración, forma parte de nuestro sistema de derecho público, dado que los primeros cuatro siglos de formación del derecho en Cuba discurrieron bajo la dominación política de España, habiéndonos dejado como legado histórico la pertenencia al sistema de derecho público franco-español. El sistema de autotutela de la Administración pública cubana tiene su anclaje en la cultura político-jurídica de nuestro país, 
no en un pronunciamiento normativo expreso. No se incorporó a la Constitución, su existencia deriva de una lectura indirecta de la construcción que la LPCALE da al proceso contencioso-administrativo. Dentro de él, el privilegio de ejecutividad de los actos toma vida indirectamente a través de la regla de la no suspensión -incorporada esta última al orden positivo cubano con el tantas veces citado art. 692 LPCALE-. Así que, como en nuestro caso, parte sustancial del régimen de autotutela administrativa se debe a la construcción legal de la jurisdicción contenciosa; con lo cual una mera modificación legal del proceso, sin necesidad de tocar a la Constitución (1976), sería suficiente para perfeccionar el régimen jurídico de la justicia cautelar administrativa. La Constitución (1976), una vez más, no pondría obstáculos, sino que dejaría vía expedita para la ordenación jurídica amplia de la tutela cautelar en el proceso administrativo.

Como bien dice un autor cubano, la jurisdicción contencioso-administrativa en Cuba no se resume al articulado de la LPCALE. Por más que en ocasiones se haga una aplicación de la jurisdicción contencioso-administrativa circunscrita a su ley procesal, hay vida para la justicia administrativa más allá del perímetro del código procesal. Así, la Ley 82 (1997) marca pautas positivas para una interpretación pro justicia administrativa, y dentro de ella, de la cautelar. Su artículo 4 establece los objetivos que deben cumplir los órganos judiciales en el ejercicio de su función; preceptúa que la actividad de los tribunales tiene por objetivo, entre otros, amparar la vida, la libertad, la dignidad, las relaciones familiares, el honor, el patrimonio y los demás derechos e intereses legítimos de los ciudadanos. Luego, el artículo 5 reitera la obligación de los tribunales de cumplir con el principio constitucional de legalidad, y a continuación en el artículo 7 se implementan los medios con los que se garantiza la ejecución efectiva de las decisiones judiciales -que al final no son más que ejecución de la ley-. Una de las vías para llevar a hechos reales el mandato de legalidad impuesto a los órganos judiciales es la obligación que los órganos estatales, entidades públicas, ciudadanos y personas jurídicas privadas tienen de cumplir las resoluciones firmes de los órganos judiciales, así como la obligación de los tribunales de ejecutar efectivamente sus fallos firmes y de vigilar el cumplimiento de estos por los organismos encargados de intervenir en el proceso de ejecución. Toda esta implementación del postulado de legalidad persigue una finalidad: está en función de amparar la vida, la libertad, la dignidad, las relaciones familiares, el honor, el patrimonio, y los demás derechos e intereses legítimos de los ciudadanos, que, junto a la meta de otorgar eficacia a las resoluciones judiciales -en expreso mandato de la I186 (2007) y la I191 (2009) - son los objetivos a los que también tributa la tutela cautelar.

La función de impartir justicia se atribuye a los órganos judiciales por expreso mandato del artículo 120 de la Constitución (1976); designación que excluye a cualquier otro órgano público de la posibilidad de decidir sobre asunto que debe ser de conocimiento judicial. El artículo 7, inciso f, de la Ley 82 (1997) 
determina que la función de los tribunales comprende juzgar y hacer ejecutar lo juzgado, con lo cual, una vez formulada ante el juez la solicitud de adopción de medida cautelar, su consecuencia fundamental sería la atribución al órgano judicial de decidir sobre la ejecutividad del acto, excluyendo la posibilidad para la Administración de emprender acciones, a partir de ese momento, para agotar los efectos de su decisión. Es decir, al amparo de estos preceptos cabe sostener que la interposición de una solicitud de medida cautelar acarrea la suspensión de la ejecutividad hasta que el juez decida sobre la medida.

Por último, no queremos concluir la exposición sobre aquellos aspectos del ordenamiento positivo cubano que tributan a una interpretación más abierta o flexible de la tutela cautelar administrativa, sin hacer referencia a lo que consideramos es una posible brecha abierta, a través de la cual podría intentarse la aplicación del régimen cautelar de la jurisdicción civil a la contenciosoadministrativa. Si bien es cierto que la tutela judicial que rige hoy por hoy en los procesos económicos y civiles no se ha extendido a la jurisdicción contencioso-administrativa, también es cierto que en virtud de la I191 (2009) ese régimen pasa a formar parte de las disposiciones del proceso civil. El profesor Grillo Longoria recuerda que el proceso civil tiene carácter supletorio para las disposiciones del proceso administrativo por expreso mandato del artículo 694 LPCALE (Grillo Longoria, 1985, p. 105). Con base en este precepto, el proceso administrativo se regirá, en lo no previsto expresamente en esa parte y con carácter supletorio, por las disposiciones del proceso civil en la forma en que resulten de aplicación.

La aplicación supletoria de la tutela cautelar civil a la contencioso-administrativa se condiciona por dos vías, una que le puede resultar favorable, otra que $\mathrm{n} .{ }^{\circ}$ La primera de ellas sujeta la aplicación supletoria de las disposiciones civiles a que no se prevea expresamente en el proceso administrativo. De esta forma, podría sostenerse que para la justicia administrativa se prevé expresamente un régimen cautelar particular, específico de ella, cuyas disposiciones están fijadas en los artículos 692 a 695 LPCALE, sin que sea posible la aplicación supletoria de la regulación cautelar civil. La segunda condición es quizás no tan visible como la primera. La última parte del artículo 694 LPCALE dispone que las disposiciones civiles sirvan supletoriamente al proceso administrativo en la forma que resulten de aplicación. Pues para determinar en qué forma esas disposiciones civiles resulten de aplicación al contencioso-administrativo podrá traerse a colación los preceptos de la 182 (1997) que determinan los objetivos o finalidad de la función judicial, los mecanismos atribuidos a los tribunales para garantizar el mandato de legalidad y el contenido de su función concretizada en juzgar y hacer ejecutar lo juzgado, de forma tal que el régimen cautelar civil resulte de aplicación al proceso administrativo a la luz del articulado de la 182 (1997), traído a colación por el artículo 694 LPCALE.

Lo cierto es que la dualidad de regulaciones cautelares en el derecho procesal cubano ha traído un régimen de desigualdad para los ciudadanos en la 
protección de sus derechos. Cuando acceden a la jurisdicción civil y económica cuentan con posibilidades distintas de justicia cautelar que cuando se ven obligados a interponer demanda en el proceso administrativo. Existe distinto grado de protección cautelar de los derechos si se acude a la justicia civil o si se marcha a la jurisdicción contencioso-administrativa.

Hasta aquí los pronunciamientos de orden positivo de los que pudiese sacarse mejor partido para ampliar el orden funcional de la justicia provisional administrativa. Una interpretación favorable a la tutela provisional en los juicios contencioso-administrativos, con el empleo de los recursos que nuestro orden positivo pone en nuestras manos, puede ser impulsada por obra de la doctrina y la jurisprudencia. Hasta el momento poco se ha logrado al respecto y mucho queda por hacer. Los verdaderos cambios, las transformaciones sustanciales deben llegar por vía legislativa, pero hasta el momento seguimos a la espera de que quienes tienen encomendada la expresión de la voluntad general se pronuncien al respecto.

\section{BIBLIOGRAFÍA}

Alcalá Zamora y Castillo, N. (2000). Proceso, autocomposición y autodefensa (contribución al estudio de los fines del proceso), México: Universidad Nacional Autónoma de México.

Álvarez Tabío, F. (1954). El proceso contencioso-administrativo. Doctrina, legislación, jurisprudencia. La Habana: Editorial Librería Martí.

Arias Gayoso, G. (2008). Reflexiones en torno al principio de legalidad y la potestad discrecional de la Administración Pública. Revista Jurídica, n. ${ }^{\circ}$ 2, pp. 25-50.

Asamblea Nacional del Poder Popular de la República de Cuba (1977). Acta de Primer Período Ordinario de Sesiones. La Habana.

BARCELONA LlOP, J. (1995). Ejecutividad, ejecutoriedad y ejecución forzosa de los actos administrativos. Santander: Universidad de Cantabria.

Bruno Dos Santos, M. A. (2012). ¿Es procedente el dictado de medidas autosatisfactivas contra la administración pública? Distintas miradas y la misma solución, pp. 334-337. En Una mirada desde el fuero contencioso-administrativo federal sobre el Derecho procesal administrativo. Buenos Aires: Fundación de Derecho Administrativo.

Calamandrei, P. (1936). Introducción al estudio sistemático de las providencias cautelares. Buenos Aires: Editorial Bibliográfica Argentina.

Cappelletti, M. y B. Garth (1996). El acceso a la justicia. La tendencia en el movimiento mundial para bacer efectivos los derechos, México: FCE. 
Carrasco Casi, M. (2006). Acceso a la justicia en el derecho administrativo. Revista Jurídica Justicia y Derecho, n. ${ }^{\circ}$.

Carré de Malberg, R. (2000). Teoría general del Estado, México: Unam.

Chinchilla Marín, C. (1999). Los criterios de adopción de las medidas cautelares en la nueva Ley reguladora de la Jurisdicción Contencioso-Administrativa, pp. 5-41. En Medidas cautelares en la jurisdicción contencioso-administrativa, Cuadernos de Derecho Judicial. Madrid: Consejo General del Poder Judicial.

Chiovenda, J. (1922). Principios de Derecho Procesal Civil, t. I. Madrid: Reus.

Del Junco y André, A. (1949). Derecho Procesal Civil, segundo curso. La Habana: Imprenta Ucar, García y Cía.

Dolz y Arango, R. (1896). Programa de Derecho Procesal Civil, Penal, Canónico y Administrativo y Teoría y práctica de instrumentos públicos. La Habana: Imprenta y Papelería "La Universal" de Ruiz y Hermano.

García de EnTERría, E. (1991). La nueva doctrina del Tribunal Supremo sobre medidas cautelares. Revista Española de Derecho Administrativo, n. ${ }^{\circ}$ 69, pp. 65-84.

García de EnTERría, E. (2006). La batalla por las medidas cautelares. Derecho comunitario europeo y proceso contencioso-administrativo español. Navarra: Thomson Civitas.

GARCÍA DE ENTERRÍA, E. (2007). Las transformaciones de la justicia administrativa: de excepción singular a la plenitud jurisdiccional. ¿Un cambio de paradigma? Navarra: Thomson Civitas.

Garcini Guerra, H. (1986). Derecho Administrativo. La Habana: Editorial Pueblo y Educación.

Goldschmidt, J. (2010). Derecho, Derecho penal y Proceso, t. II, Derecho procesal civil. Madrid: Marcial Pons.

Gordillo, A. (2006). Tratado de Derecho Administrativo, t. II, La defensa del usuario y el administrado. Buenos Aires: Fundación de Derecho Administrativo.

Grillo longoria, R.; G. De Vera Sánchez y C. R. Grillo González (1985). Derecho Procesal Civil II y III. La Habana: Editorial Pueblo y Educación.

LAFERRIÉRE, F. J. (2007). El juez administrativo francés y la urgencia, pp. 191-208. En Contencioso Administrativo. Culturas y Sistemas Jurídicos Comparados. México: Unam.

Maques Battaglia, N. F. y M. J. SaC. (2012). Las medidas cautelares contra la Administración Pública, pp. 41-62. En Una mirada desde el fuero contencioso-administrativo 
federal sobre el Derecho procesal administrativo. Buenos Aires: Fundación Derecho de Administrativo.

Marcheco Acuña, B. (2009). El control judicial de la potestad discrecional de la administración pública en Cuba. Revista Facultad de Derecho y Ciencias Políticas Universidad Pontificia Bolivariana Colombia, vol. 39, pp. 57-75.

MarCheco Acuña, B. (2012). Del régimen de medidas cautelares y de la ejecución de sentencias en el Proceso Administrativo cubano, pp. 235-263. En Panorama del Derecho procesal bispanocubano. Valencia: Tirant lo Blanch.

Mata Marcano, G. (2010). La reforma del Contencioso-Administrativo: estudio comparativo entre la Ley orgánica del Tribunal Supremo de Justicia y la nueva Ley orgánica de la jurisdicción contencioso-administrativa. Anuario de Derecho, n. ${ }^{\circ} 27$, pp. 15-54.

Matilla Correa, A. (2003). Sistema de fuentes del Derecho administrativo. Temas de Derecho Administrativo cubano. La Habana: Editorial Félix Varela, pp. 39-240.

Matilla Correa, A. (2013). La justicia administrativa en Cuba: inicios y evolución hasta la primera intervención norteamericana, pp. 381-416. En El Derecho público en Cuba a comienzos del siglo XXI. Homenaje al Dr. Fernando Álvarez Tabío. La Habana: Editorial $\mathrm{uH}$.

Maurer, H. (2011). Derecho Administrativo, Parte General. Madrid: Marcial Pons.

Mendoza DíAZ, J. (2007). Un acercamiento al régimen cautelar del proceso económico cubano. Boletín Organización Nacional de Bufetes Colectivos, n. ${ }^{\circ}$ 29, pp. 1-27.

Mendoza Díaz, J. (2012). Un acercamiento al Proceso Civil cubano, pp. 93-132. En Panorama del Derecho procesal bispanocubano. Valencia: Tirant lo Blanch.

Montero Aroca, J. (1994). La berencia procesal española. México: Unam.

Pacteau, B. (2005). Contentieux administratif. Paris: Editorial PUf.

PARada VÁzquez, J. R. (1968). Privilegio de decisión ejecutoria y proceso contencioso. Revista de Administración Pública, n. ${ }^{\circ}$ 55, pp. 65-112.

Pereira Basanta, J. (2012). Sobre el recurso de plena jurisdicción y otros presupuestos de acceso a la justicia administrativa en Cuba. Apunte para una trayectoria histórica. Boletín del Ministerio de Justicia, n. ${ }^{\circ}$ 2147, pp. 1-60.

Pérez GutiérRez, I. (2010). Del régimen cautelar en el contexto del proceso civil cubano. Tesis presentada en opción al grado científico de Doctor en ciencias jurídicas. La Habana: Facultad de Derecho, Universidad de La Habana. 
Pérez GutiérreZ, I. (2012). Lo cautelar en el Proceso Civil cubano, pp. 195-234. En Panorama del Derecho procesal bispanocubano. Valencia: Tirant lo Blanch.

Pielow, J. C. (2007). El acceso a la justicia administrativa. En Contencioso-administrativo. Culturas y sistemas jurídicos comparados. México: Unam.

Remigio Ferro, R. (1999). Discurso pronunciado con motivo del 25 aniversario de los Tribunales Populares. Revista Cubana de Derecho, n. ${ }^{\circ}$ 13, pp. 67-70.

SAntamaría PAstor, J. A. (1983). Tutela judicial efectiva y no suspensión en vía de recurso. Revista de Administración Pública, n. ${ }^{\circ}$ 100-102, pp. 1609-1627.

Santamaría Pastor, J. A. (2010). La Ley Reguladora de la Jurisdicción Contencioso-Administrativa. Comentario. Madrid: Iustel y Gómez-Acebo \& Pombo.

TomÁs y Valiente, F. (2004). Manual de Historia del Derecho español. Madrid: Tecnos.

\section{ReFERENCiAS LEGALES (Cuba)}

Pacto Internacional de Derechos Civiles y Políticos (1966), Resolución n. ${ }^{\circ} 2200$ A (XXI), Asamblea General de las Naciones Unidas.

Constitución de la República de Cuba (1976). Gaceta Oficial de la República de Cuba Edición Especial, n. ${ }^{\circ} 2$.

Ley de Enjuiciamiento Civil (1885). Establecimiento Tipográfico P. Núñez, Madrid.

Ley n. ${ }^{\circ} 1261$ de Procedimiento Civil y Administrativo (1974). Publicación de Legislaciones, vol. IV, La Habana, Ministerio de Justicia.

Ley n. ${ }^{\circ} 7$ de Procedimiento Civil, Administrativo y Laboral (1977), Gaceta Oficial de la República de Cuba, Edición Ordinaria, n. ${ }^{\circ} 34$.

Ley n. ${ }^{\circ} 82$ de los Tribunales Populares (1997), Gaceta Oficial de la República de Cuba, Edición Extraordinaria, n. ${ }^{\circ} 8$.

Decreto Ley n. ${ }^{\circ} 241$ (2006). Gaceta Oficial de la República de Cuba, Edición Extraordinaria, n. ${ }^{\circ} 33$.

Instrucción n. ${ }^{\circ} 186$ (2007). Gaceta Oficial de la República de Cuba, Edición Ordinaria, n. ${ }^{\circ} 79$.

Instrucción n. 191 (2009). Gaceta Oficial de la República de Cuba, Edición Extraordinaria, n. ${ }^{\circ} 17$. 
REFERENCIAS LEGALES EXTRANJERAS (POR ORDEN DE APARICIÓN EN EL TEXTO)

Ley de lo Contencioso-Administrativo (1888). Gaceta de Madrid, n. 258.

Ley Reguladora de la Jurisdicción Contencioso Administrativa (1956). Boletín Oficial del Estado, 28 de diciembre.

Ley de la Jurisdicción Contencioso-Administrativa (1960). Boletín Oficial Federal (BGBL) I.

Ley Orgánica de la Jurisdicción Contencioso Administrativa (2010). Gaceta Oficial de la República Bolivariana de Venezuela, n. ${ }^{\circ} 39.447$.

Ley Federal de Procedimiento Contencioso Administrativo (2005). Diario Oficial de la Federación $1^{\circ}$ de diciembre.

Ley 1/2000, de 7 de enero, de Enjuiciamiento Civil. Boletín Oficial del Estado n. ${ }^{\circ}$, de 8 de enero.

Auto (1991). Tribunal Supremo español, Sala 3a, Sección 6a.

Zuckerfabrik Süderdithmarschen y Zuckerfabrik Soest. Asuntos acumulados C-143/88 y C-92/89. Sentencia Zuckerfabrik. Tribunal de Justicia de la Unión Europea (1991).

Fruchthandelsgesellschaft mbH y otros contra Bundesamt für Ernährung und Forstwirtschaft. Asunto C-465/93. Sentencia Atlanta. Tribunal de Justicia de la Unión Europea (1995). 